\title{
Thermo-mineral waters from the Cerna Valley Basin (Romania)
}

\author{
Ioan POVARÃ ${ }^{1 *}$, Georgel SIMION2† \& Constantin MARIN ${ }^{1}$ \\ ${ }^{1}$ „Emil Racoviță” Institute of Speleology, Frumoasă 31, 78114, Bucharest, Romania \\ ${ }^{2}$ S.C. Prospecțiuni SA, Caransebeş 1, 12271, Bucharest, Romania († deceased)
}

Received: May 2008, accepted November 2008

Available online November 2008

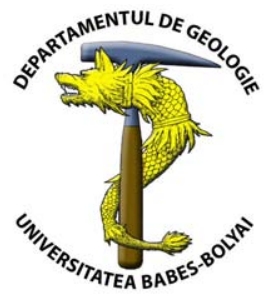

\begin{abstract}
In the Cerna Valley basin, located southwest of the Southern Carpathians and upstream from the confluence of Cerna with Belareca, an aquifer complex has developed. The basin is strongly influenced by hydrogeothermal phenomena, acting within two major geological structures, the Cerna Syncline and the Cerna Graben. The complex consists mainly of Jurassic and Cretaceous carbonate rocks, as well as the upper part of the Cerna Granite that is highly fractured, tectonically sunken into the graben. The geothermal investigations have shown the existence of some areas with values of the geothermal gradient falling into the $110-200^{\circ} \mathrm{C} / \mathrm{km}$ interval, and temperatures of $13.8-16^{\circ} \mathrm{C}$ at the depth of $30 \mathrm{~m}$. The zone with the maximal flux intensity is situated between the Băile Herculane railway station and the Crucea Ghizelei Well, an area where 24 sources (10 wells and 14 springs) are known. The geothermal anomaly is also extended to the south (Topleț), north (Mehadia) and NE (Piatra Puşcată), a fact, which is stressed by the existence of hypothermal springs with low mineralization. The physical-chemical parameters of the sources show a strong N-S variability. At the entire thermo-mineral reservoir scale, the temperature of the water sources, the total mineralization, and the $\mathrm{H}_{2} \mathrm{~S}$ quantity are increasing from the north to the south, and the $\mathrm{pH}$ and natural radioactivity are following the same trend.
\end{abstract}

Key words: thermo-mineral waters, karst, hydrogeology, hydrochemistry, Cerna Valley, Romania.

\section{GENERAL DATA}

The thermo-mineral reservoir from Băile Herculane, with its extensions towards the north and the south, is framed within the hydrographic basin of the Cerna. The Cerna River has maintained its current flow direction (NNESSW) since the end of the Tortonian, creating a straightlined valley along a major tectonic feature, which can be followed from the Jiul de Vest up to the south of the Danube (the Jiu-Cerna Fault). Cerna divides two well-defined mountain units. To the west, the Cerna Mountains descend from over $1700 \mathrm{~m}$ in the northern extremity, to only $500 \mathrm{~m}$ at the Cerna-Belareca confluence. Towards the east, the Mehedinți Mountains have a maximum altitude of $1446 \mathrm{~m}$ in Vârful lui Stan (Stan's Peak) and over 700 m above Băile Herculane. The leveling area Râu Şes is present in both massifs; however, it is better developed in the Mehedinți Mountains, where it occupies large surfaces on Urgonian limestones (Râu Şes Karst Plain).

The tributaries on the right side of Cerna are numerous, and most of them are perennial, unlike those on the left side, which are fewer and flow is intermittent. Exceptions are only the Arşasca, Roşeț and Slatina tributaries.

The meteorological parameters are typical for the temperate continental climate with Mediterranean influences, specific for the southwestern territory of Romania. Average rainfall and annual temperatures for 26 years (1979-2004) were $718.4 \mathrm{~mm}$, respectively $10.3^{\circ} \mathrm{C}$, in Băile Herculane, and $1058 \mathrm{~mm}$, respectively $8.3^{\circ} \mathrm{C}$, in
Cerna-Sat. A value of more than $33 \%$ of the total annual rainfall has been recorded in April-June, while the lowest quantity has been registered in January-March (16.8\%). The snow layer shows a low persistence even in altitudes higher than $700 \mathrm{~m}$, due to the frequent warm air invasions during the winter period.

\section{History of research}

The natural springs from Băile Herculane were known and used by the Romans (107-287 A.D.), the therapeutic qualities of the water being mentioned in many votive tables currently kept in the Natural History Museum in Vienna. Some hydrochemical data and summary references to the origin of the thermal waters have been published abroad since the $17^{\text {th }}$ century, in works with descriptive character. The first information on the stratigraphy and the tectonics of the region dates back to the second half of the $19^{\text {th }}$ century. Extremely important are the works of Murgoci $(1905,1910)$ and Codarcea (1940). The last author elaborated both the first stratigraphic sketch of the region and the first interpretation of the tectonic evolution of this part of the Southern Carpathians, both still valid. In the second half of the last century, Năstăseanu (1967, 1980), Codarcea and Năstăseanu (1964) and Codarcea et al. (1967) completed and detailed the previous knowledge.

The present information on the thermo-mineral waters dates only from the beginning of last century, and the researchers preoccupied by the hydrogeological aspects of 
the region are many: Popescu-Voiteşti (1921), Papiu (1960), Pascu (1968), Pricăjan et al. (1972), Povară (1973, 1980, 1992), Povară et al. (1972), Vasilescu and Liteanu (1973), Povară and Lascu (1978), Slăvoacă et al. (1978), Povară and Marin (1984), Simion et al. (1984), and Gaşpar (1994).

Significant parts of the studies are focused on the geophysical prospections (magnetometric, electrometric, thermometric, and biophysical), the results of which are included in specialized reports or have been published by Visarion et al. (1974), Povară (1992), and Mitrofan et al. (1995).

\section{Temperature and mineralization of waters: hypotheses on their origin}

Concerning the origin of the waters moving within the Băile Herculane Reservoir, several hypotheses have been elaborated, each of these underlining the role of the surface waters infiltrated through karst rocks.

The hypothesis of the juvenile origin, initiated by Popescu-Voiteşti (1921), considers the sources in Băile Herculane as fumarolic type phenomena, characterized by the large quantity of water vapors, hydrogen sulfide, and chlorides, a consequence of the decomposition of the ammonium chloride. The pulsating character of the flow rates and gas emissions in some sources, a specific phenomenon of magmatic activity, represents for Pascu (1968) an argument supporting this hypothesis.

The hypothesis of vadose origin, elaborated by Papiu (1960) and supported by Vasilescu and Liteanu (1973), considers the geothermal step as the major cause of heating. Superficial waters deeply penetrate on the transversal faults to the major structures, getting the temperature according to the depth and returning to surface strongly heated. Studies conducted after 1950 have brought important additional data regarding the temperature and the mineralization of sources:

- the washing of the lagoon deposits by the deeply infiltrated waters and the reduction of the sulfates to $\mathrm{H}_{2} \mathrm{~S}$ by the means of the organic substances (Oncescu, 1953);

- the presence of specific ions in the water of the sources;

- the increase of the dissolving capacity of certain minerals from the Barremian-Aptian marly limestones and the Senonian flysch, due to the high temperature of waters originating initially from the surface (Papiu, 1960); under the influence of the overheated water vapors, the pyrite is converted to ferrous monosulfide, and then to $\mathrm{H}_{2} \mathrm{~S}$.

The hypothesis of the mixed origin has been supported by Simion (1987) and Simion and Popescu (1988), who reached the conclusion that the thermo-mineral waters from Băile Herculane represent the result of the mixing of three hydrogeological components: one cold component (the dominant percentage), a heating component (hot vapors heating cold waters), and a mineralizing component, coming from outside the Cerna Graben, which mineralizes the already heated waters.

The author admits that a part of the ions contained in the waters, as well as free gases (methane and superior homologues, nitrogen and helium), may have an ascensional origin, together with the overheated vapors from the depth of the area, even from the upper part of the mantle. In this case, the two components (mineralizing and heating) are mixed.

\section{GEOLOGICAL AND HYDROGEOLOGICAL CHARACTERIZATION OF THE REGION}

The region where the thermo-mineral reservoir from Băile Herculane is developed geologically consists of formations pertaining to the Danubian Autochthonous (Presacina and Cerna sedimentation areas) and from the crystalline formations of the Getic Nappe. The Neamţu Series and the Cerna Granite, locally covered by Permian conglomerates in Verrucano facies, represent the basement.

A suite of Jurassic-Cretaceous sediments, including an important carbonate sequence, transgressively covers the autochthonous paleorelief. The Jurassic sediments are developed on the right slope of Cerna and in the graben. It is represented by a conglomeratic sandstone series, shales, clastic limestones, and spathic limestones, 50-75 m thick $\left(\mathrm{J}_{1}-\mathrm{J}_{2}\right)$, on top of which a carbonate sequence is located, $100-200 \mathrm{~m}$ thick $\left(\mathrm{J}_{3}-\mathrm{be}\right)$, consisting of sandstone-like limestones with chert nodules, massive and bedded (in metric banks) limestones. The Cretaceous follows in depositional continuity, being represented by a 50-75 m thick, limestone pile, in plates, with marly limestone intercalations (Valanginian-Hauterivian), and by compact or schistous marly limestones (Iuta Layers), 200-250 m thick, assigned to Barremian-Aptian (Năstăseanu, 1980).

On the left slope of Cerna, synchronically with the Iuta Layers, slightly recrystallized or massive coral limestones directly overlay the basement and are covered by the wildflysch and the Mehedinţi Flysch Formation. The Getic Nappe is represented by oblong strips of crystalline schists, sunken into the Cerna Graben or situated at 150-200 $\mathrm{m}$ above it.

From a tectonic point of view, two major structures are involved in the functioning of the thermo-mineral aquifer from Băile Herculane, the Cerna Syncline (developed on the right slope of the river) and the Cerna Graben (formed between two deep fractures, NNE-SSW oriented, between which a subsidence of more than $1000 \mathrm{~m}$ occurred), respectively. The western fracture is considered as crustal or subcrustal (Bercia, 1975) and is very important hydrogeologically. The two structures can communicate hydrodynamically, uni- or bilaterally. The most important transversal fractures from the Băile Herculane perimeter are the Hercules, Munk, Diana, Neptun, and Vicol faults. On their intersection with the western fault of the Cerna Graben or immediately nearby, thermo-mineral sources are present.

\section{Cerna Syncline}

The Cerna Syncline may be axially followed, for a distance of $25 \mathrm{~km}$, between the Topenia Brook (to the north) and Băile Herculane, where it joins the Cerna Graben (Fig. 1). This represents an important hydrogeological structure, due to the presence of a complex of Jurassic and Cretaceous carbonate rocks, the first with significant aquifer properties. The syncline shows a pronounced asymmetry, due to the eastward reversal of its western flank, effect of the tangential movements, which acted on the west-east direction. On both flanks, the rocks outcrop only in the area of the Grota cu Aburi [Steam Cave] (Băile Herculane) and northward from the Bedina Brook. Between these points, the western flank tails out, being tectonically covered by other formations. As a result, the outcropping area of the limestones is reduced (less than $5 \%$ of the surface of the right slope of Cerna), implying also a small catchment area. 


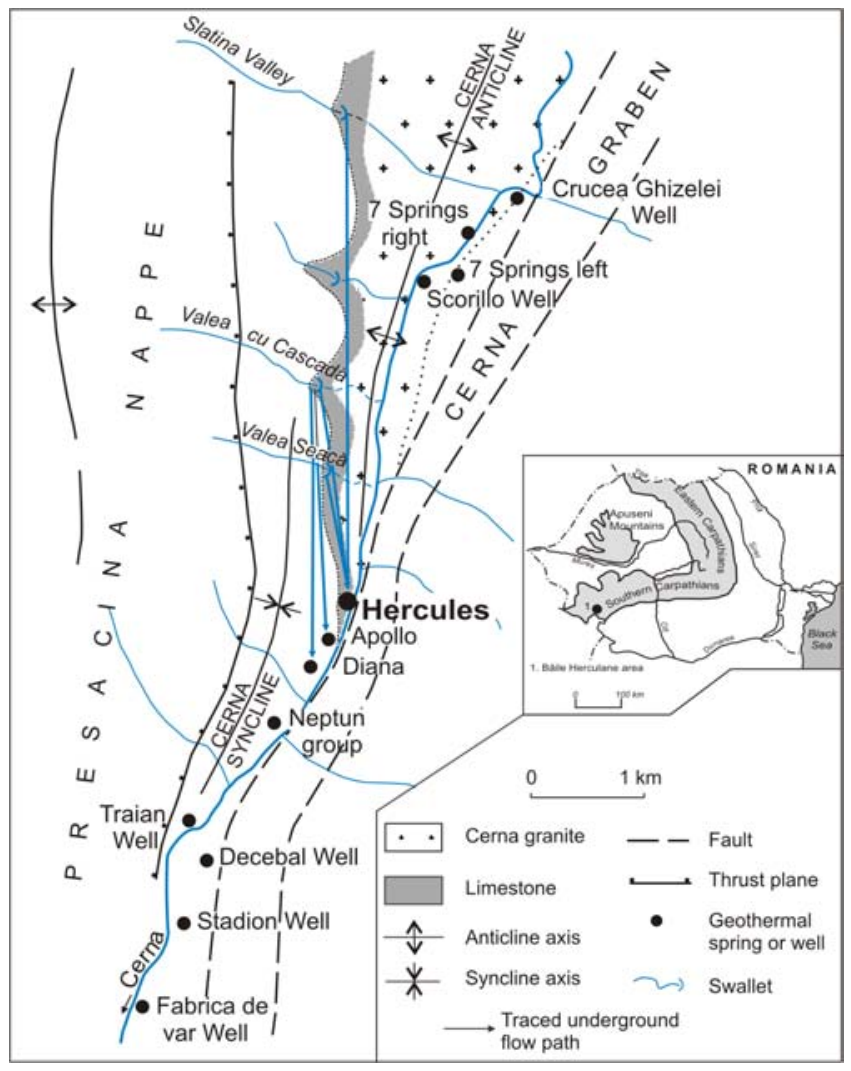

Fig. 1. Geological and hydrogeological sketch of the Băile Herculane area.
The outcropping area of limestones is deeply cut by karstified lithoclases, but also by a relief of towers and vents specific for limestone bars. The endokarst is represented by small cavities. Four caves and a pothole: Grota cu Aburi, Hercules Cave, Despicătură Cave, Diana Cave, and Adam's Pothole, all located in the southern part of the syncline, are influenced by the thermal phenomena acting within the area (Table 1).

Tributaries on the right side of Cerna are obsequent related to the structure. When crossing limestones, short gorges sectors are formed where the runoff collected upstream, on non-karst formations, is diffusely caught in the underground circulation. The sector located upstream from the limestones remains dry during drought periods.

Results obtained using radioactive and fluorescent tracers injected in Cerna and in some of its tributaries on the right side (Table 2) have led to the following conclusions:

- the Cerna River does not supply the aquifer from the Cerna Syncline;

- losses from tributaries on the right side of Cerna, south of Iuta Valley, provide an underground drainage along the structure, supplying thermo-mineral sources south of the syncline (Hercules and Apollo springs), but also the Şapte Izvoare Calde [Seven Warm Springs] (right), which is discharging the aquifer from the Cerna Graben. This implies a hydraulic link between the Cerna Graben and the Cerna Syncline;

- outflows situated south of the Grota cu Aburi parallel (Hercules, Apollo, Diana and Neptun) are supplied with cold waters originating from the syncline.

In the area between the Diana and Neptun outflows, the Cerna Syncline is joined with the Cerna Graben, most probably along the western fault of the latter.

Table 1. Some characteristics of the thermally-influenced caves from Băile Herculane.

\begin{tabular}{lccccl}
\hline \multicolumn{1}{c}{ Name } & Rel. alt. & Abs. alt. & $\mathrm{L}(\mathrm{m})$ & $\mathrm{D}(\mathrm{m})$ & \multicolumn{1}{c}{ Thermal phenomena } \\
\hline Diana Cave* & 7 & 152.5 & 14 & -2.5 & Thermo-mineral water: $\mathrm{T}=51 \pm 1^{\circ} \mathrm{C}$ \\
Despicătură Cave** & 4 & 155.8 & 105 & +1 & Thermo-mineral water: $\mathrm{T}=18-53.4^{\circ} \mathrm{C}$ \\
Hercules Cave & 5.5 & 157.5 & 94.5 & $+5 ;-6.5$ & Thermo-mineral water: $\mathrm{T}=17-53.5^{\circ} \mathrm{C}$ \\
Adam's Pothole & 139 & 293.3 & 169 & -27 & Vapours: $\mathrm{T}=29.8-46.5^{\circ} \mathrm{C}$ \\
Grota cu Aburi & 230 & 382.9 & 14 & +7 & Vapours: $\mathrm{T}=52.8-54.5^{\circ} \mathrm{C}$ \\
\hline
\end{tabular}

Table 2. Water tracing in the Cerna Graben and in the Cerna Syncline.

\begin{tabular}{|c|c|c|c|c|c|c|c|c|c|c|}
\hline \multicolumn{5}{|c|}{ SURFACE INFLOW } & \multicolumn{6}{|c|}{ OUTFLOW } \\
\hline Nr. & Surface inflow & Author and year & Tracer & $\mathrm{H}(\mathrm{m})$ & Spring/well & $\mathrm{H}(\mathrm{m})$ & $\mathrm{L}(\mathrm{km})$ & $\Delta \mathrm{H}(\mathrm{m})$ & Time & $\mathrm{V}(\mathrm{m} / \mathrm{h})$ \\
\hline 1 & \begin{tabular}{|l} 
Valea Seacă [Dry Valley] \\
\end{tabular} & ISPIF, 1971 & ${ }^{131} \mathrm{I}$ & 320 & Hercules & 155 & 1.5 & 165 & 20 & 37 \\
\hline 2 & Slatina Valley & ISPIF, 1971 & ${ }^{131} \mathrm{I}$ & 550 & Hercules & 155 & 3.5 & 395 & 42 & 83.3 \\
\hline 3 & Valea Seacă & ISER, 1976 & $\mathrm{~F}$ & 320 & Hercules & 155 & 0.74 & 165 & 41 & 18 \\
\hline 4 & Valea cu Cascadă [Waterfall Valley] & ISER, 1976 & $\mathrm{~F}$ & 380 & Hercules & 155 & 1.15 & 225 & 161 & 7.1 \\
\hline 5 & Valea cu Cascadă & ISER, 1976 & $\bar{F}$ & 380 & Hercules & 155 & 1.15 & 225 & 182 & 6.3 \\
\hline \multirow{2}{*}{6} & \multirow{2}{*}{ Valea cu Cascadă } & \multirow{2}{*}{ ISER, 1976} & \multirow{2}{*}{$\mathrm{F}$} & \multirow{2}{*}{380} & Hercules & 155 & 1.15 & 225 & 162 & 7.1 \\
\hline & & & & & Apollo II & 152 & 1.5 & 228 & 218 & 6.9 \\
\hline 7 & Grota cu Aburi & ISER, 1976 & $\mathrm{~F}$ & 383 & Hercules & 155 & 0.35 & 228 & 118 & \\
\hline 8 & Bobot Gorges & IPG+IFA, 1976 & ${ }^{3} \mathrm{H}$ & 375 & $\begin{array}{l}\text { The tracer emerged } \\
\text { Crucea Ghizelei, Di }\end{array}$ & $\begin{array}{l}0 \text { Şapte I } \\
\text { na and } \mathrm{P}\end{array}$ & $\begin{array}{l}\text { evoare R } \\
\text { eptun (qL }\end{array}$ & $\begin{array}{l}\text { ci [Seven } \\
\text { alitative ir }\end{array}$ & $\begin{array}{l}\text { old } S p r \\
\text { formati }\end{array}$ & $n g s]$, \\
\hline \multirow{4}{*}{9} & \multirow{4}{*}{ Valea cu Cascadă } & \multirow{4}{*}{ IPG+IFA, 1979} & \multirow{4}{*}{${ }^{131} \mathrm{I}$} & \multirow{4}{*}{380} & Hercules & 155 & 1.15 & 225 & 194 & 5.92 \\
\hline & & & & & Apollo II & 152 & 1.5 & 228 & 252 & 5.95 \\
\hline & & & & & Diana & 150 & 1.85 & 230 & 407 & 4.54 \\
\hline & & & & & Neptun & 148 & 2.3 & 232 & 479 & 4.8 \\
\hline \multirow{2}{*}{10} & \multirow{2}{*}{ Găuri Valley } & \multirow{2}{*}{ ISER, 1976} & \multirow{2}{*}{$\mathrm{F}$} & \multirow{2}{*}{320} & Hercules & 155 & 2.52 & 165 & 214 & 11.8 \\
\hline & & & & & Apollo II & 152 & 2.87 & 168 & & \\
\hline \multirow{2}{*}{11} & \multirow{2}{*}{ Iuta Valley } & \multirow{2}{*}{ ISER, 1977} & \multirow[t]{2}{*}{$\mathrm{F}$} & \multirow{2}{*}{370} & Şapte Izvoare Reci & 176 & 9.6 & 194 & 139 & 68.8 \\
\hline & & & & & Crucea Ghizelei & 202 & 12.4 & 168 & 248 & 50 \\
\hline \multirow{2}{*}{12} & \multirow{2}{*}{ Iuta Valley } & \multirow{2}{*}{$\begin{array}{l}\text { IPG+IFA, } \\
\text { ISER, } 1978\end{array}$} & \multirow[t]{2}{*}{${ }^{131} \mathrm{I}$} & \multirow{2}{*}{370} & Piatra Puşcată & 340 & 0.3 & 30 & & \\
\hline & & & & & Şapte Izvoare Reci & 176 & 9.6 & 194 & 137 & 70 \\
\hline \multirow[t]{2}{*}{13} & \multirow[t]{2}{*}{ Țesna Glades } & \multirow[t]{2}{*}{ IPG+IFA, 1979} & \multirow[t]{2}{*}{${ }^{131} \mathrm{I}$} & 320 & $\begin{array}{l}\text { Sapte Izvoare } \\
\text { Calde (right) }\end{array}$ & 169 & 7.87 & 151 & 257 & 30.6 \\
\hline & & & & & Hercules & 155 & 10.62 & 165 & 330 & 32.2 \\
\hline 14 & Valen cu Cascadă & IPG+IFA 1979 & ${ }^{131} \mathrm{~J}$ & 380 & Hercules & 155 & 1.15 & 225 & 295 & 3.9 \\
\hline 14 & valea cu cascadra & 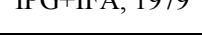 & & & Apollo II & 152 & 1.5 & 228 & 500 & \\
\hline
\end{tabular}

IPG - Geological Prospecting Company; IFA - Institute of Atomic Physics; ISER - "Emil Racoviță" Institute of Speleology; F - fluorescein. 


\section{Cerna Anticline}

The Cerna Anticline is also located on the right slope of Cerna and is framed by the Cerna Syncline (to the west) and by the Cerna Graben (to the east). In the axial area, it includes the Cerna Granite, and on its flanks, the Mesozoic sedimentary cover of the Danubian Autochthonous. Its western flank is related to the eastern one of the Cerna Syncline, while the eastern flank is sunken into the graben. Both folded structures are eastward-inclined.

The non-karst rocks from the anticline are acting as a hydrogeological barrier, causing a north-south underground drainage of the water from the syncline, along the axis. Under these circumstances, water discharge to the east is not possible.

\section{Cerna Graben}

The Cerna Graben is NNE-SSW oriented, approximately parallels the Cerna Syncline, and is extended for a distance of more than $60 \mathrm{~km}$. Northward from the Topenia Valley, it is covered by the crystalline Getic Nappe.

The rocks with aquifer properties are limestones and the upper part of the granites, affected by open fissures, through which the thermal and mineralized waters flow. The geometry of the karst aquifer is determined by the two faults, eastern, and western, probably transcrustal or subcrustal; by the granite-carbonate rocks boundary at the lower part, and by the limestone-Cretaceous wildflysch boundary, at the upper part.

The hydrogeological profile (Fig. 2a), drawn along the southern graben of the T,esna Valley, shows three important aspects (Povară and Lascu, 1978):

- Rocks with aquifer properties are sunken into the Cerna Graben at various depths, along transversal faults, which delineate distinct blocks. In most cases, these show a hydrodynamic link throughout the limestone massif;

- Limestones outcrop at the level of the riverbed at the points Bobot Gorges, Piatra Puşcată, Şapte Izvoare Reci and Sapte Izvoare Calde (right), a fact which makes possible the existence of water infiltrations from Cerna;

- Between Şapte Izvoare Calde and the Hercules Spring, the crystalline-granite basement is rising to the surface, forming "the Granite Sill Şapte Izvoare Calde-Hercules". Northward and southward from the sill, two distinct aquifer complexes are developed.

The northern aquifer complex covers a distance of ca. $30 \mathrm{~km}$, between the Bobot Gorges (to the north) and the hydrogeological threshold created by the granite pluton outcropping in the Şapte Izvoare Calde sector (Fig. 2b). The reservoir rock consists mainly in $\mathrm{J}_{3}-\mathrm{K}_{2}$ limestones, $150-520 \mathrm{~m}$ thick. These are covered by the non-karst deposits of the Cretaceous wildflysch, reaching $480 \mathrm{~m}$ maximal thickness.

The Cerna River crosses this structure longitudinally, so there is a possibility of water infiltration from the river into the graben, on the open areas of the longitudinal and transversal fractures or directly through the limestones located in the Cerna riverbed.
Measurements performed by INMH Bucharest have shown that on the section situated between Piatra Puşcată (to the north) and Crucea Ghizelei (to the south), the infiltrations volume amounts to $300 \mathrm{l} / \mathrm{s}$. Starting from these premises, in 1976 Simion and Gaşpar injected, in the north of the sector (Bobot Gorges), marked tritium (Gaşpar and Simion, 1985). The experiment has proven the supply of the northern aquifer complex from Cerna, but also the flow of cold waters towards the Crucea Ghizelei, Diana and Neptun thermo-mineral sources.

Simion (1987) considers that the rising of the basement from the Şapte Izvoare Reci area, along with the sedimentary rocks overlaying it, on a system of three transversal faults, creates a tectonic threshold. This structure forces the emergence of the waters flowing from the north, but also, at low flow rates, allows the waters circulation towards the southern subcompartment. The cumulated flow rates of the Şapte Izvoare Reci, originating especially from infiltrations in the Cerna riverbed, may exceed $300 \mathrm{l} / \mathrm{s}$, and the springs have an artesian character that has been highlighted in 1978 by an ISPIF well drilled directly in the Cerna riverbed, at ca. $10 \mathrm{~m}$ from the natural springs. South of the Şapte Izvoare Reci, the Crucea Ghizelei Well has been drilled, the water of which is of karst nature, with low mineralization $(0.250-0.450 \mathrm{~g} / \mathrm{l})$, but thermal $\left(31-37^{\circ} \mathrm{C}\right)$.

The Granite Sill Şapte Izvoare Calde-Hercules consists in a massive Cerna Granite intrusion, intensely fissured, and a thin cover of sedimentary rocks, from which limestones are lacking or are very thin. This compartment has a major hydrogeological importance, since it blocks or limits the southward flow of the karst waters from the northern aquifer complex, thus preventing a pronounced dilution of the thermo-mineral waters from the southern aquifer complex. Three thermo-mineral sources are situated in this compartment: the Scorilo Well, Şapte Izvoare Calde (right) and Şapte Izvoare Calde (left).

The southern aquifer complex is extended between the Hercules Spring and the railway station Băile Herculane, for approximately $5 \mathrm{~km}$. More varied from a lithological and a structural point of view, it is better known than the northern complex. Hydrogeological wells (most of them carriers of thermo-mineral waters) highlighted the same vertical lithological succession, as well as the general tendency to southward sinking of some compartments delimited by transversal faults. Since the JurassicCretaceous karstified limestones store important volumes of water and are covered by non-karst deposits (pertaining to the wildflysch facies or to the Getic crystalline), this aquifer complex is confined. In the Hercule Spring-Diana Spring area, the graben is in tectonic contact with the Cerna Syncline. The thermal waters are ascending on the transversal fractures (Hercules, Diana, Neptun and Vicol faults) or through karst voids, and emerge as springs or in wells, with artesian character. The sources in the junction area between the Cerna Syncline and the Cerna Graben suffer a periodic dilution with cold waters. 

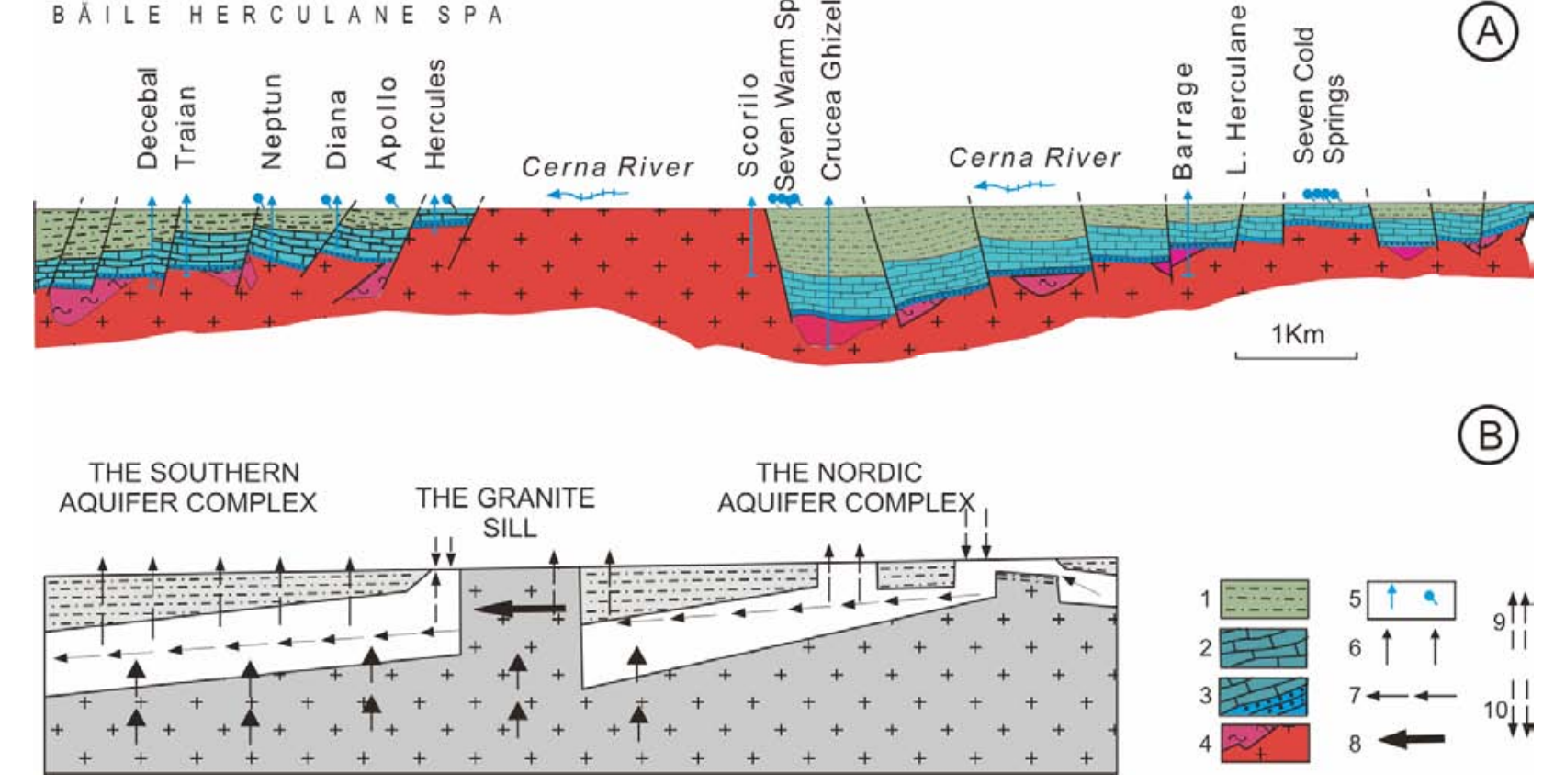

Fig. 2. Hydrogeological profile through the Cerna Graben and organization pattern of aquifer structures and underground flow from the Cerna Graben: 1 - marls, flysch $\left(K_{2}\right) ; 2$ - limestones $\left(J_{2}-K_{1}\right)$; 3 - conglomerates, sandstones, shales $\left(P-J_{1}\right) ; 4$ - crystalline-granite basement (Ptz); 5 - well; natural spring; 6 - thermal supply on transversal faults; 7 - karst longitudinal flow; 8 - longitudinal flow on the western fault of the graben; 9 - ascending circulation on transversal faults; 10 - descending supply (according to Povară and Lascu, 1978).

\section{RESULTS OBTAINED BY GEOPHYSICAL METHODS}

\section{Geothermometry}

The geothermal studies conducted by Veliciu et al. (1983) in 30-50 $\mathrm{m}$ deep wells, led to the delineation of several anomalous areas, characterized by values of the superficial gradients higher than $90^{\circ} \mathrm{C} / \mathrm{km}$ and by temperatures higher than $12^{\circ} \mathrm{C}$, are considered as reference for the area (Table 3). The above-mentioned authors have shown that these anomalies are caused by the heat energy emanating from inside the Earth, on the transcrustal faults, which delimit the Cerna Graben. The fact has been confirmed by the superficial gradients, which are constant $\left(50^{\circ} \mathrm{C} / \mathrm{km}\right)$ outside the anomalous areas. Within the anomalies, the thermal transfer to the surface is dominantly convective and is generated by the movement of the heated waters and water vapors. In the absence of the heated waters and vapors, the heat transfer in the rocks takes place by conduction.

The surface geothermometry measurements have been performed between the Munk Spring and the Hercules Cave and highlighted alignments with positive anomalies, separated by corridors of minimum, WNW-ESE or W-E oriented (Visarion et al., 1974). On these alignments, the Apollo and Despicătura sources are located, but also the vapors emissions from the Adam's Pothole and Grota cu Aburi. Most anomalies are placed on the Neptun, Diana, Apollo, and Despicătura transversal faults. The geothermal flow has maximal values in the limestone and minimal in other types of rocks. This means that the limestone lithoclases, enlarged by dissolution, are the most conductive structures for the geothermal flow.

\section{Underground geothermometry (Hercules mining gallery)}

Near the Hercules Spring, in the eastern flank of the Cerna Syncline, predominantly in the Jurassic limestones, a mining gallery has been dug in order to catch the thermal waters not mixed with cold karst waters. The gallery intercepted the karst drain from which the spring is supplied, in the prolongation of the Hercules Cave. Geothermometric measurements in the wells westward performed in this gallery (up to a maximum of $140 \mathrm{~m}$ depth) have shown horizontal geothermal gradients of $0.93-2.92^{\circ} \mathrm{C} / 100 \mathrm{~m}$ (Veliciu et al., 1987; Povară, 1992), as well as the fact that in the dry rock, the conductive heat transfer is very slow (Mitrofan and Povară, 1992).

\section{Electrometric prospections}

Electrometric prospections (resistivity and potential natural), performed between the Valea Seacă, Grota cu Aburi and Hercules Cave (Mitrofan et al., 1995), has brought forward additional data concerning the position of the karst drain from the southern part of the Cerna Syncline, confirming the results obtained using tracers.

\section{Seismometric radio-transparency measurements}

Seismometric radio-transparency measurements outlined several highly permeable, intensely fissured areas, with warm water flow. These are located towards the western flank of the Cerna Syncline and they confirmed, as well, the geothermometric data and those obtained using tracers. On the whole, the results of the geophysical measurements have made available elements of spatial distribution, absolutely necessary in order to design a coherent model of the water mixing mechanism. 
Table 3. Geothermally anomalous areas from the Cerna Valley Basin (Simion, 1987).

\begin{tabular}{clccc}
\hline Nr. & \multicolumn{1}{c}{ Area } & $\begin{array}{r}\mathrm{T}\left({ }^{\circ} \mathrm{C}\right) \text { at } 30 \mathrm{~m} \\
\text { depth }\end{array}$ & $\begin{array}{c}\text { Superficial geothermal } \\
\text { gradient }\left({ }^{\circ} \mathrm{C} / \mathrm{km}\right)\end{array}$ & Axial extension \\
\hline 1 & Piatra Puşcată & 13.8 & $110-160$ & $\begin{array}{c}\text { Between Presacina and Topenia confluences } \\
\text { with Cerna }(\sim 12 \mathrm{~km})\end{array}$ \\
2 & Şapte Izvoare Calde & 16 & 200 & $3-4 \mathrm{~km}$ \\
3 & Băile Herculane & 14 & $110-200$ & $\begin{array}{c}\text { Between the Cerna-Şaua Padina confluence } \\
\text { and Fabrica de Var }(4 \mathrm{~km})\end{array}$ \\
4 & Pecinișca & $14-14.5$ & $110-160$ & $\sim 1.5 \mathrm{~km}$ \\
5 & Topleț & 15.8 & 190 & $\sim 3 \mathrm{~km}$ \\
6 & Mehadia & 13.1 & 98 & $\sim 2 \mathrm{~km}$ \\
\hline
\end{tabular}

\section{CHEMICAL CHARACTERISTICS OF THE WATER SOURCES}

Many processes related to the waters accumulated at depth mark the development area of the thermo-mineral water reservoir from Băile Herculane. The waters ascend and emerge as springs located on transversal fractures, or as artesian wells, due to the reservoir pressure or due to a gas lift natural process. On the whole, the aquifer structures previously mentioned discharge a minimal cumulated flow rate of $55 \mathrm{l} / \mathrm{s}$, and a maximal cumulated flow rate of $154.25 \mathrm{l} / \mathrm{s}$, by a number of 14 more important springs and 10 wells.
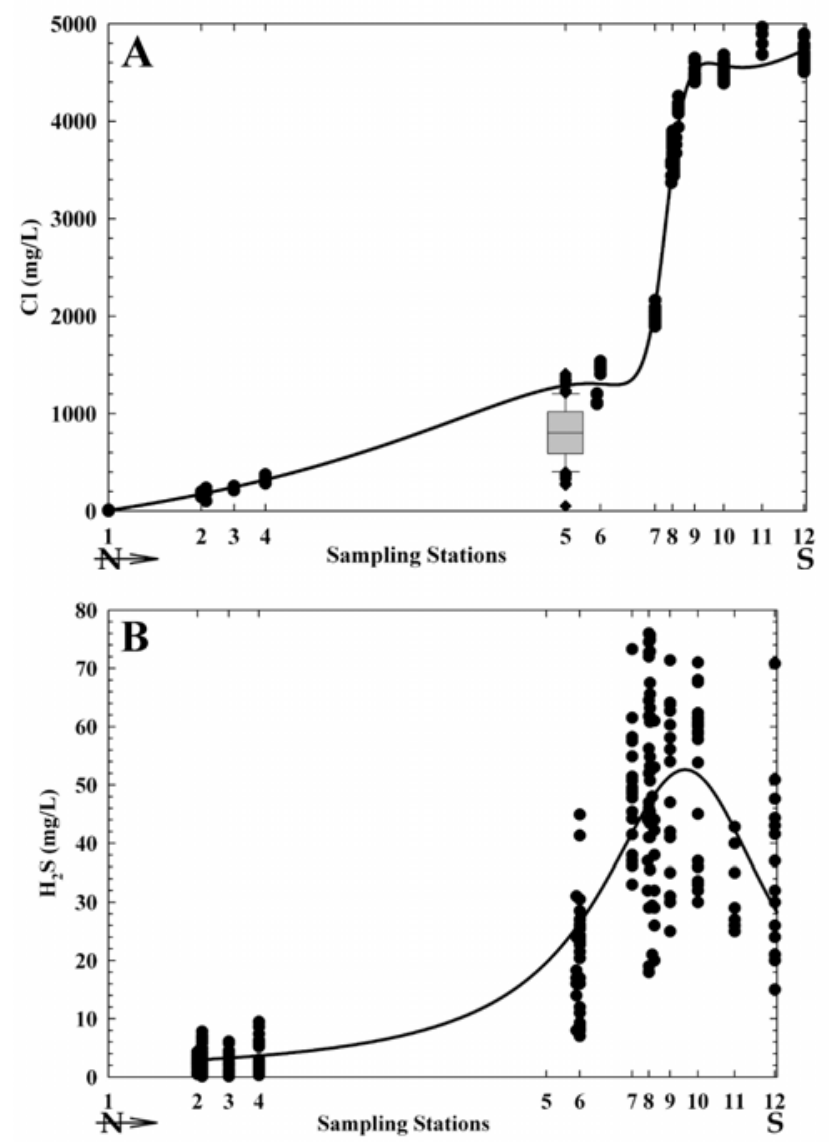

Fig. 3. Distribution of chloride (A) and dissolved $\mathrm{H}_{2} \mathrm{~S}$ concentrations $(B)$ in the water of the thermo-mineral sources from Băile Herculane; the sampling stations (from $N$ to $S$ ) are represented, according to the distances between them:

1 - Crucea Ghizelei Well; 2 - Şapte Izvoare Calde (right);

3 - Şapte Izvoare Calde (left); 4 - Scorilo Well; 5 - Hercules I Spring; 6 - Apollo Group (I and II); 7 - Diana III Well;

8 - Neptun Group (Neptun I+IV, Anteu, Argus); 9 - Traian Well; 10 - Decebal Well; 11 - Fabrica de Var Well; 12 - Stadion Well.

In order to describe the thermo-mineral water chemical characteristics, one should investigate: the hydrochemical facies, the mineralization level and the hydrogen sulfide $\left(\mathrm{H}_{2} \mathrm{~S}\right)$ presence. The values for flow rate, water temperature, and TDS mentioned within this chapter, as well as in the $3^{\text {rd }}$, $4^{\text {th }}$, and $6^{\text {th }}$ columns of Table 4 have been obtained by different institutions up to the year 1990. Groundwater is predominantly of $\mathrm{Na}-\mathrm{Cl}$ type, with a total content in dissolved solids exceeding $9.7 \mathrm{~g} / 1$ at some springs and wells; except in two cases, $\mathrm{H}_{2} \mathrm{~S}$ is present in all the other discharge points (Table 4). In general, one can note an increase in the mineralization of the springs and wells, from the north to the south of the reservoir, while the $\mathrm{H}_{2} \mathrm{~S}$ concentrations are similarly increasing (Fig. 3).

Some specifications on the temperature of the thermomineral waters can be obtained by the means of the diagram elaborated by Giggenbach (1986).

The assumption of the method is that the relative concentrations of $\mathrm{K}, \mathrm{Na}, \mathrm{Mg}$, and $\mathrm{Ca}$ in thermal waters at equilibrium with a stable thermodynamic mineral system are, at a certain temperature, unique. In solutions, the pair $\mathrm{K}-\mathrm{Na}$ comes in equilibrium very slowly or only at very high temperatures, while the relative concentrations $\mathrm{K}-\mathrm{Mg}$ come in equilibrium quickly and at low temperatures. This means that the first pair will indicate the temperature of water at the source level, and the second, much less stable, the distance from it.

The graphic processing (Fig. 4) shows for all sources an equilibrium temperature of $170-190^{\circ} \mathrm{C}$, which is by far superior to the maximal one recorded when the wells have been initiated (Mitrofan and Povară, 2000). This would imply that the $\mathrm{K}-\mathrm{Na}$ balance takes place either deeper, below the granites or inside them, or outside the graben. The farthest source to the hearth is Crucea Ghizelei, while the closest ones are included in the southern group.

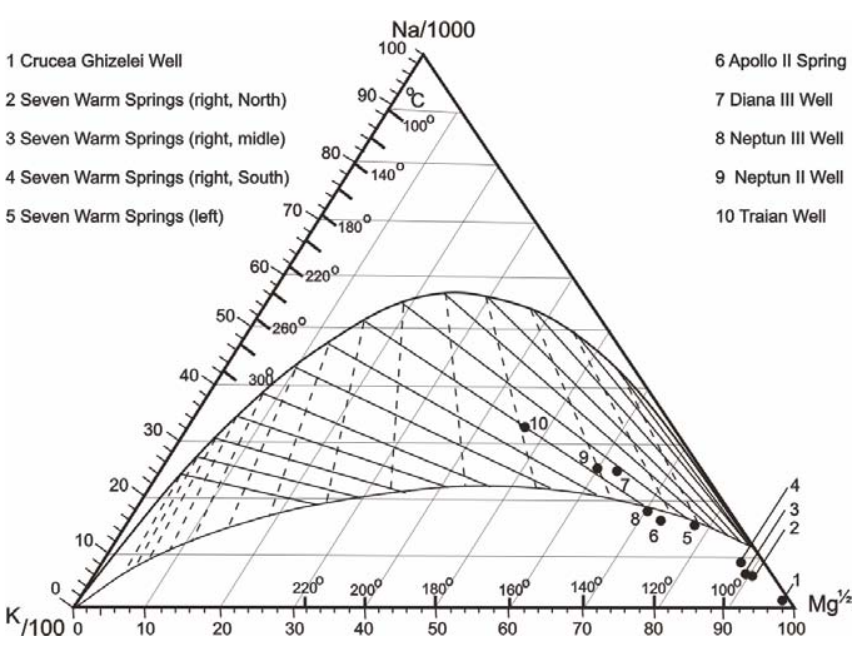

Fig. 4. Giggenbach diagram - the assessment of the equilibrium temperature for the $\mathrm{K}-\mathrm{Na}$ and $\mathrm{K}-\mathrm{Mg}$ pairs at certain sources from Băile Herculane (Mitrofan and Povară, 2000). 
Table 4. Some physico-chemical characteristics of the water of the main thermo-mineral sources from the Cerna Valley (1984-1995).

\begin{tabular}{|c|c|c|c|c|c|c|c|c|c|c|c|c|c|c|}
\hline & & $\begin{array}{l}\mathbf{Q} \\
1 / \mathrm{s}\end{array}$ & $\begin{array}{l}\mathrm{T} \\
{ }^{\circ} \mathrm{C} \\
\end{array}$ & pH & $\begin{array}{c}\text { TDS } \\
\mathrm{g} / \mathrm{L}\end{array}$ & $\begin{array}{c}\mathbf{H}_{2} \mathbf{S} \\
\mathrm{mg} / \mathrm{L} \\
\end{array}$ & $\begin{array}{c}\mathbf{N a} \\
\mathrm{mg} / \mathrm{L}\end{array}$ & $\begin{array}{c}\mathbf{K} \\
\mathrm{mg} / \mathrm{L}\end{array}$ & $\begin{array}{c}\mathbf{M g} \\
\mathrm{mg} / \mathrm{L}\end{array}$ & $\begin{array}{l}\mathrm{Ca} \\
\mathrm{mg} / \mathrm{L}\end{array}$ & $\begin{array}{l}\mathrm{HCO}_{3} \\
\mathrm{mg} / \mathrm{L}\end{array}$ & $\begin{array}{c}\mathrm{Si} \\
\mathrm{mg} / \mathrm{L}\end{array}$ & $\begin{array}{c}\mathbf{S O}_{4} \\
\mathrm{mg} / \mathrm{L}\end{array}$ & $\begin{array}{c}\mathbf{C l} \\
\mathrm{mg} / \mathrm{L}\end{array}$ \\
\hline 1 & 2 & 3 & 4 & 5 & 6 & 7 & 8 & 9 & 10 & 11 & 12 & 13 & 14 & 15 \\
\hline \multirow{3}{*}{$\begin{array}{c}\text { Crucea Ghizelei Well } \\
{[\mathrm{n}=26]} \\
\mathrm{n}=\text { number of samples }\end{array}$} & Min. & 7.2 & 28.0 & 7.0 & 0.2 & - & 0.2 & 0.1 & 7.0 & 39.3 & 171.4 & 0.4 & 1.9 & 0.5 \\
\hline & Max. & 11.7 & 41.5 & 8.0 & 0.5 & - & 35.0 & 3.0 & 26.0 & 70.0 & 341.0 & 6.6 & 24.4 & 14.0 \\
\hline & Med. & & 34.3 & 7.4 & 0.3 & - & 5.7 & 0.8 & 12.8 & 53.9 & 230.9 & 3.2 & 6.9 & 4.2 \\
\hline \multirow{3}{*}{$\begin{array}{l}\text { Şapte Izvoare Calde (right } \\
\text { downstream*) } \\
{[\mathrm{n}=28]}\end{array}$} & Min. & 1.45 & 41.0 & 6.8 & 0.4 & 0.1 & 120.6 & 4.0 & 0.4 & 14.5 & 52.7 & 8.3 & 98.0 & 104.0 \\
\hline & Max. & 2.12 & 56.6 & 7.9 & 0.8 & 41.2 & 232.0 & 12.2 & 5.3 & 40.1 & 97.0 & 31.6 & 218.0 & 236.4 \\
\hline & Med. & 1.63 & 53.7 & 7.5 & 0.6 & 5.4 & 178.9 & 6.3 & 1.0 & 21.7 & 69.0 & 17.9 & 120.0 & 189.9 \\
\hline \multirow{3}{*}{$\begin{array}{l}\text { Şapte Izvoare Calde (left) } \\
\qquad[\mathrm{n}=28]\end{array}$} & Min. & 0.1 & 37.0 & 7.1 & 0.6 & 0.1 & 106.0 & 5.0 & 0.3 & 24.6 & 54.0 & 6.5 & 72.5 & 212.0 \\
\hline & Max. & 1.6 & 42.5 & 7.8 & 0.9 & 43.9 & 259.0 & 13.2 & 59.0 & 44.0 & 115.0 & 26.4 & 203.0 & 255.0 \\
\hline & Med. & 0.63 & 40.5 & 7.5 & 0.7 & 5.6 & 196.5 & 6.8 & 3.3 & 29.4 & 76.7 & 14.5 & 116.0 & 236.3 \\
\hline \multirow{3}{*}{$\begin{array}{l}\text { Scorilo Well } \\
\quad[\mathrm{n}=24]\end{array}$} & Min. & 0.77 & 48.4 & 6.9 & 0.7 & 0.3 & 188.0 & 6.0 & 0.3 & 26.2 & 42.0 & 6.5 & 69.1 & 283.0 \\
\hline & Max. & 1.04 & 53.0 & 7.6 & 0.9 & 42.0 & 285.0 & 72.0 & 4.8 & 45.0 & 97.6 & 28.8 & 203.0 & 375.1 \\
\hline & Med. & 0.90 & 51.4 & 7.3 & 0.8 & 7.6 & 236.1 & 11.4 & 1.3 & 32.3 & 57.0 & 16.8 & 117.5 & 310.0 \\
\hline \multirow{3}{*}{$\begin{array}{l}\text { Hercules Spring } \\
\quad[\mathrm{n}=209]\end{array}$} & Min. & 10.2 & 17.0 & 7.0 & 0.3 & - & 29.4 & 1.6 & 49.0 & 1.9 & 84.0 & 4.2 & 31.0 & 52.0 \\
\hline & Max. & 105 & 53.5 & 7.6 & 2.5 & - & 543.2 & 29.7 & 352.6 & 7.0 & 131.4 & 14.5 & 120.0 & 1407.0 \\
\hline & Med. & 25.9 & 32.6 & 7.3 & 1.6 & - & 307.7 & 16.8 & 228.1 & 4.5 & 111.2 & 9.2 & 72.5 & 799.0 \\
\hline \multirow{3}{*}{$\begin{array}{l}\text { Apollo II Well } \\
\quad[\mathrm{n}=27]\end{array}$} & Min. & 1.5 & 44.8 & 6.3 & 2.4 & 0.8 & 553.0 & 23.0 & 0.5 & 300.4 & 16.3 & 9.0 & 12.0 & 1390.0 \\
\hline & Max. & 3.6 & 50.2 & 7.3 & 2.8 & 44.9 & 741.0 & 45.6 & 17.0 & 428.0 & 109.0 & 23.6 & 184.0 & 1595.0 \\
\hline & Med. & 2.78 & 47.9 & 6.9 & 2.6 & 18.5 & 639.1 & 31.4 & 6.0 & 323.7 & 60.1 & 13.9 & 105.2 & 1479.6 \\
\hline \multirow{3}{*}{$\begin{array}{l}\text { Diana III Spring } \\
\quad[\mathrm{n}=31]\end{array}$} & Min. & 0.03 & 51.8 & 6.9 & 2.6 & 3.0 & 568.2 & 4.2 & 1.1 & 101.0 & 6.1 & 4.3 & 1.2 & 1454.9 \\
\hline & Max. & 0.05 & 55.0 & 8.2 & 5.8 & 73.3 & 1777.0 & 68.0 & 14.5 & 649.0 & 201.0 & 24.7 & 207.0 & 3368.0 \\
\hline & Med. & 0.04 & 54.4 & 7.6 & 3.7 & 35.5 & 977.9 & 38.2 & 6.2 & 387.9 & 76.0 & 12.6 & 65.8 & 2141.3 \\
\hline \multirow{3}{*}{$\begin{array}{l}\text { Neptun II (Anteu) Well } \\
{[\mathrm{n}=21]}\end{array}$} & Min. & 0.01 & 45.0 & 7.0 & 4.7 & 18.0 & 1134.9 & 52.0 & 2.2 & 626.0 & 6.3 & 8.3 & 1.4 & 2884.2 \\
\hline & Max. & 0.02 & 49.0 & 7.6 & 6.8 & 98.5 & 1729.0 & 77.0 & 35.6 & 981.0 & 183.0 & 16.5 & 182.0 & 3900.0 \\
\hline & Med. & 0.015 & 47.4 & 7.3 & 6.2 & 54.3 & 1465.0 & 63.3 & 12.3 & 828.9 & 69.4 & 12.4 & 86.6 & 3682.9 \\
\hline \multirow{3}{*}{$\begin{array}{l}\text { Neptun III (Argus) Well } \\
{[\mathrm{n}=29]}\end{array}$} & Min. & 0.03 & 48.9 & 6.9 & 5.1 & 22.0 & 1169.0 & 5.0 & 2.4 & 705.0 & 13.3 & 1.4 & 33.6 & 3049.0 \\
\hline & Max. & 0.18 & 59.0 & 8.0 & 6.5 & 75.7 & 1583.0 & 103.0 & 49.7 & 969.0 & 134.0 & 28.2 & 211.0 & 3811.0 \\
\hline & Med. & 0.08 & 46.0 & 7.4 & 6.0 & 45.9 & 1413.5 & 57.2 & 14.3 & 813.0 & 67.0 & 13.7 & 117.2 & 3568.0 \\
\hline \multirow{3}{*}{$\begin{array}{l}\text { Traian Well } \\
{[\mathrm{n}=27]}\end{array}$} & Min. & 5.2 & 52.9 & 7.0 & 6.2 & 13.0 & 796.0 & 57.0 & 4.8 & 846.6 & 48.0 & 5.4 & 22.0 & 3684.2 \\
\hline & Max. & 7.0 & 59.5 & 7.8 & 9.3 & 115.9 & 1948.0 & 89.6 & 749.0 & 1458.0 & 158.0 & 20.1 & 816.0 & 5319.0 \\
\hline & Med. & 6,6 & 58.6 & 7.4 & 7.5 & 49.4 & 1691.8 & 70.4 & 42.4 & 1025.4 & 123.1 & 12.2 & 108.1 & 4427.4 \\
\hline \multirow{3}{*}{$\begin{array}{l}\text { Decebal Well } \\
\quad[\mathrm{n}=25]\end{array}$} & Min. & 1.3 & 34.0 & 7.1 & 7.0 & 21.0 & 1526.2 & 37.0 & 2.4 & 799.0 & 106.7 & 15.4 & 21.8 & 4205.1 \\
\hline & Max. & 2.9 & 38.7 & 7.9 & 8.5 & 83.9 & 2149.0 & 93.0 & 67.9 & 1120.0 & 173.0 & 74.7 & 211.0 & 4964.0 \\
\hline & Med. & 1.7 & 36.2 & 7.5 & 7.6 & 51.4 & 1778.4 & 68.3 & 21.7 & 1019.2 & 130.4 & 36.2 & 84.6 & 4522.5 \\
\hline \multirow{3}{*}{$\begin{array}{l}\text { Fabrica de Var Well } \\
\qquad[\mathrm{n}=11]\end{array}$} & Min. & 3.1 & 27.0 & 7.3 & 7.8 & 18.0 & 1678.0 & 5.0 & 6.3 & 976.0 & 73.0 & 7.7 & 46.0 & 4680.0 \\
\hline & Max. & 4.5 & 42.2 & 7.7 & 9.7 & 42.8 & 2592.0 & 72.0 & 24.0 & 1206.0 & 122.0 & 27.6 & 259.0 & 5744.0 \\
\hline & Med. & 3.6 & 38.1 & 7.5 & 8.3 & 30.2 & 1982.3 & 59.3 & 10.5 & 1068.8 & 96.3 & 18.2 & 114.1 & 4916.7 \\
\hline \multirow{3}{*}{$\begin{array}{l}\text { Stadion Well } \\
\quad[\mathrm{n}=16]\end{array}$} & Min. & 0.5 & 28.5 & 7.1 & 7.5 & 5.0 & 1595.0 & 6.0 & 2.4 & 827.0 & 73.0 & 9.2 & 15.0 & 4503.0 \\
\hline & Max. & 1.9 & 37.0 & 7.6 & 9.0 & 78.8 & 2396.0 & 88.0 & 97.0 & 1126.0 & 99.0 & 23.7 & 203.0 & 5389.0 \\
\hline & Med. & 0.9 & 32.4 & 7.3 & 7.9 & 36.7 & 1904.8 & 64.9 & 38.3 & 995.4 & 84.9 & 15.7 & 87.1 & 4702.3 \\
\hline
\end{tabular}

\section{COMPOSITION AND ORIGIN OF THE NATURAL GASES}

Most sources of thermo-mineral water bring to surface important quantities of gas (Table 5). Gases from the Crucea Ghizelei Well have a composition close to the atmospheric air. In the Scorilo Group, nitrogen is very increased (97\%) and methane appears, as well as low quantities of $\mathrm{H}_{2} \mathrm{~S}$. As for the sources from the southern groups, a major change of concentrations is recorded. Methane percentage increases to $60-70 \%$, the nitrogen quantity diminishes to $30-45 \%$, and the argon diminishes to $0.42-0.47 \%$. The presence of methane could be related to the coal deposit in Mehadia, from where it migrates in the graben, on transversal faults, while nitrogen and argon have an internal chemical origin (Mastan et al., 1982).

The most radioactive gases (Şapte Izvoare Calde Right) have the lowest content in helium, while the less radioactive ones (southern groups) have the highest helium content.
Helium is considered to be mainly of juvenile origin, and only secondarily of radiogenic origin. The gas radioactivity is usually reaching less than $1 \mathrm{nCi} / \mathrm{lN}$. The radioactive character of waters is determined by the radon radioactivity. The most radioactive gas sample has been measured at the Şapte Izvoare Calde Right, the values diminishing southward (Cosma et al., 1981).

The chemical composition and the radioactivity of the reservoir waters confirm the deep origin of the thermal and mineralized component.

\section{THERMO-MINERAL WATER RESERVOIR}

Depending on the ways of access to the surface and on the areal distribution of the emergence points, the thermomineral water sources have been included in 5 groups (Simion, 1986), each of them being also individualized by distinct hydrochemical peculiarities. 
Table 5. Composition and radioactivity of the natural gases emanated from the water of the thermo-mineral outflows (Cosma et al., 1981; Mastan et al., 1982).

\begin{tabular}{|c|l|r|r|r|r|r|r|r|r|r|}
\hline \multirow{2}{*}{ Nr. } & \multicolumn{1}{|c|}{ Outflow } & \multicolumn{9}{|c|}{ Gas composition (\%) } \\
\cline { 3 - 10 } & & $\mathrm{CH}_{4}$ & \multicolumn{1}{|c|}{$\mathrm{N}_{2}$} & $\mathrm{C}_{2} \mathrm{H}_{6}$ & $\mathrm{Ar}$ & $\mathrm{O}_{2}$ & \multicolumn{1}{c|}{$\mathrm{H}_{2} \mathrm{~S}$} & $\mathrm{CO}_{2}$ & $\mathrm{Ar} / \mathrm{N}_{2}(\%)$ & $\mathrm{nCi} / \mathrm{IN}$ \\
\hline 1 & Crucea Ghizelei Well & - & 82.62 & - & 1.469 & 14.73 & - & 1.178 & - & - \\
\hline 2 & Scorilo Well & 1.649 & 96.78 & - & 1.51 & 0.012 & 0.004 & 0.049 & 1.558 & - \\
\hline 3 & Sapte Izvoare Calde (right) & 1.099 & 97.03 & - & 1.508 & 0.268 & - & 0.095 & 1.554 & 113.54 \\
\hline 4 & Neptun Well & 53.669 & 44.391 & 1.06 & 0.703 & 0.017 & 0.005 & 0.155 & 1.584 & - \\
\hline 5 & Venera Spring & 62.670 & 35.651 & 0.856 & 0.525 & 0.020 & 0.008 & 0.270 & 1.473 & 1.23 \\
\hline 6 & Traian Well & 64.594 & 33.600 & 0.751 & 0.425 & 0.052 & 0.176 & 0.402 & 1.265 & 30.16 \\
\hline 7 & Decebal Well & 67.953 & 30.386 & 0.819 & 0.529 & 0.029 & 0.006 & 0.278 & 1.741 & - \\
\hline 8 & Stadion Well & 66.044 & 32.825 & 0.567 & 0.747 & 0.005 & - & 0.084 & 1.444 & 12.37 \\
\hline 9 & Fabrica de Var Well & 65.536 & 33.110 & 0.851 & 0.446 & 0.016 & 0.005 & 0.036 & 1.347 & - \\
\hline 10 & Mehadica Valley & 0.796 & 96.595 & - & 1.739 & 0.078 & - & 0.792 & 1.800 & - \\
\hline
\end{tabular}

\section{Şapte Izvoare Calde (Seven Warm Springs) Group}

Crucea Ghizelei Well. Due to its physical-chemical properties, this is a special source, which we present within this group only by the reason of its position. The Well was dug in 1970, up to $1201 \mathrm{~m}$, and it crossed a limestone sequence with an apparent thickness of more than $500 \mathrm{~m}$ (Fig. 5). Hydrogeological tests highlighted well-differentiated aquifer properties of the limestones (Vasilescu and Liteanu, 1973):

- compact, less fissured between 540-800 m, producing a flow rate of $0.3 \mathrm{l} / \mathrm{s}$ at $35^{\circ} \mathrm{C}$ and $+29 \mathrm{~m}$ artesian pressure;

- intensely fissured under the $800 \mathrm{~m}$ depth, with frequent dissolution voids and artesian flow (+29 m); flow rate: 10.22 $1 / \mathrm{s}$ at $35.5^{\circ} \mathrm{C}$.

Water is constantly of the $\mathrm{Ca}-\mathrm{HCO}_{3}, \mathrm{H}_{2} \mathrm{~S}$-depleted type, with very low mineralization $(0.25-0.45 \mathrm{~g} / \mathrm{l})$.

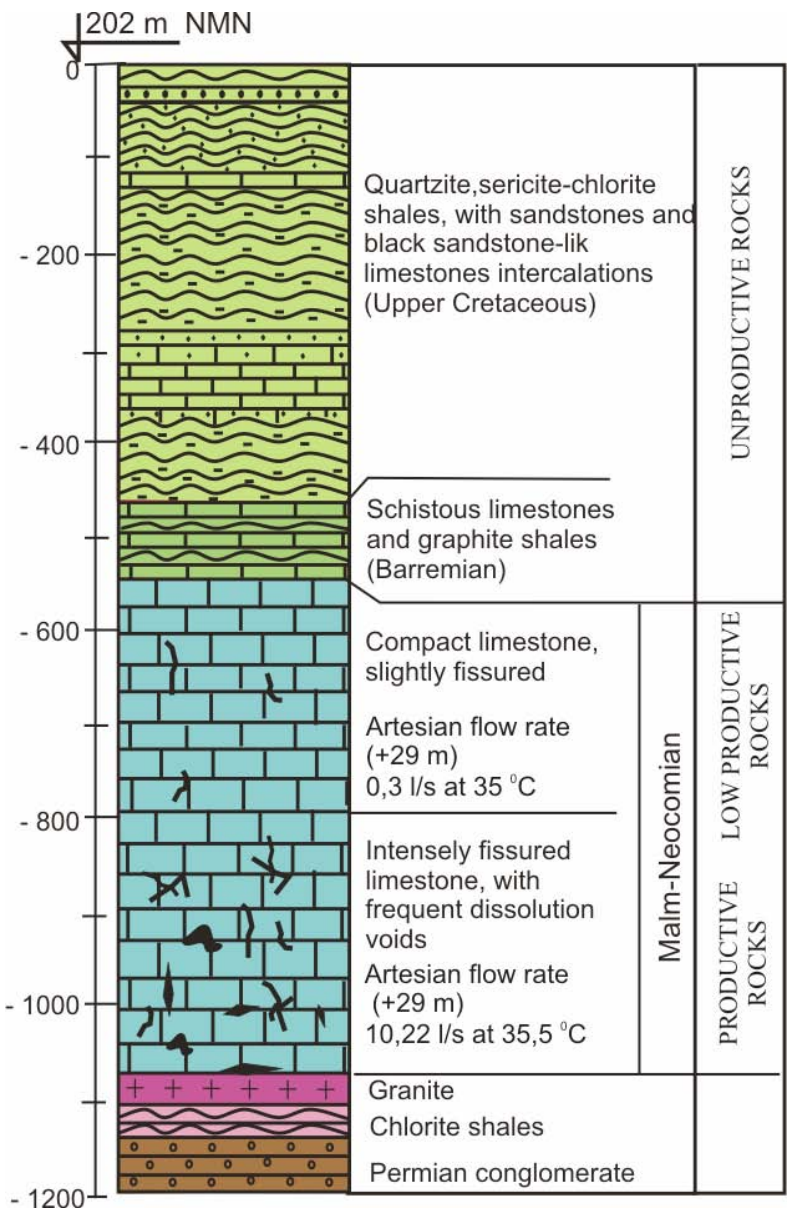

Fig. 5. Lithostratigraphic column of the Crucea Ghizelei Well.
Sapte Izvoare Calde (right). More than 30 natural springs of thermo-mineral water, distributed on a nearly $50 \mathrm{~m}$ front, varied in flow rate, are located in the right bank of Cerna (Fig. 6). The water emerges on the tectonic contact between the Cerna Granite and the Mesozoic limestones, a fact which explains the total flow rates of more than $2 \mathrm{l} / \mathrm{s}$. Chemically, the water of the springs is of $\mathrm{Na}-\mathrm{Cl}$ type, with an average value of $5.2 \mathrm{mg} \mathrm{H}_{2} \mathrm{~S} / 1$ and a low mineralization $(0.55-0.76 \mathrm{~g} / \mathrm{l})$.

Sapte Izvoare Calde (left) are situated on the opposite bank, $300 \mathrm{~m}$ downstream and emerge from the granite, on a $20 \mathrm{~m}$ front, as exfiltrations, totalizing flow rates of 0.1-1.6 1/s and temperatures of $37-41^{\circ} \mathrm{C}$. Chemically, the waters of these emergences are similar to the previous, belonging to the $\mathrm{Na}$ $\mathrm{Cl}$, low-sulfide type, with low mineralization (0.65-0.74 g/l).

Scorilo Well. This Well is located $85 \mathrm{~m}$ downstream from the previous springs, in the left slope of Cerna, above the flooding level. The Well crossed Quaternary layers, $2 \mathrm{~m}$ thick, and then only granites, down to the final depth of $549.5 \mathrm{~m}$. The aquifer properties of the granite are vertically non-homogeneous. The interval comprised between 60 and $150 \mathrm{~m}$, has an ascending character, with a water level situated at $-0.1 \mathrm{~m}$, whereas the interval defined between 498 $\mathrm{m}$ and $549.5 \mathrm{~m}$ has an artesian character, NP being situated at $+24 \mathrm{~m}$. For the years 1988,1989 , and 1994, temperatures varied in the $48.4^{\circ} \mathrm{C}-51.3^{\circ} \mathrm{C}$ range, and the flow rates between $0.77-1.01 \mathrm{l} / \mathrm{s}$. The waters of this source are, as the previous ones, of $\mathrm{Na}-\mathrm{Cl}$, low-sulfide type, with very low mineralization (0.65-0.85 g/l after 1974).

\section{Hercules Group}

It includes four springs where the most important variations of the flow rate and temperature have been noted; two of them, Hercules and Apollo, equal the cumulated flow rates of all the other sources.

The Hercules Spring is the most important source of flow rate, but has the most instable physical-chemical properties. It emerges from homonymous cave and represents the main discharge of the karst aquifer developed in the Cerna Syncline (Fig. 7). The variation range of the flow rates covers $94.8 \mathrm{l} / \mathrm{s}$ (between 10.2 and $105 \mathrm{l} / \mathrm{s}$ ), while that of the temperatures is $36.5^{\circ} \mathrm{C}\left(17.0-53.5^{\circ} \mathrm{C}\right)$. The total mineralization varies between $0.29-2.51 \mathrm{~g} / \mathrm{l}$. The water characteristics are changing depending on the flow rate, turning from a Na$\mathrm{Cl}$ facies (at low flow rates), to a $\mathrm{Ca}-\mathrm{HCO}_{3}$ one (at high flow rates). The mixture of waters with different origin facilitates the total oxidation of $\mathrm{H}_{2} \mathrm{~S}$ to $\mathrm{SO}_{4}{ }^{2-}$, the concentrations of the latter increasing in reverse proportion with the flow rate values (Marin, 1984). 


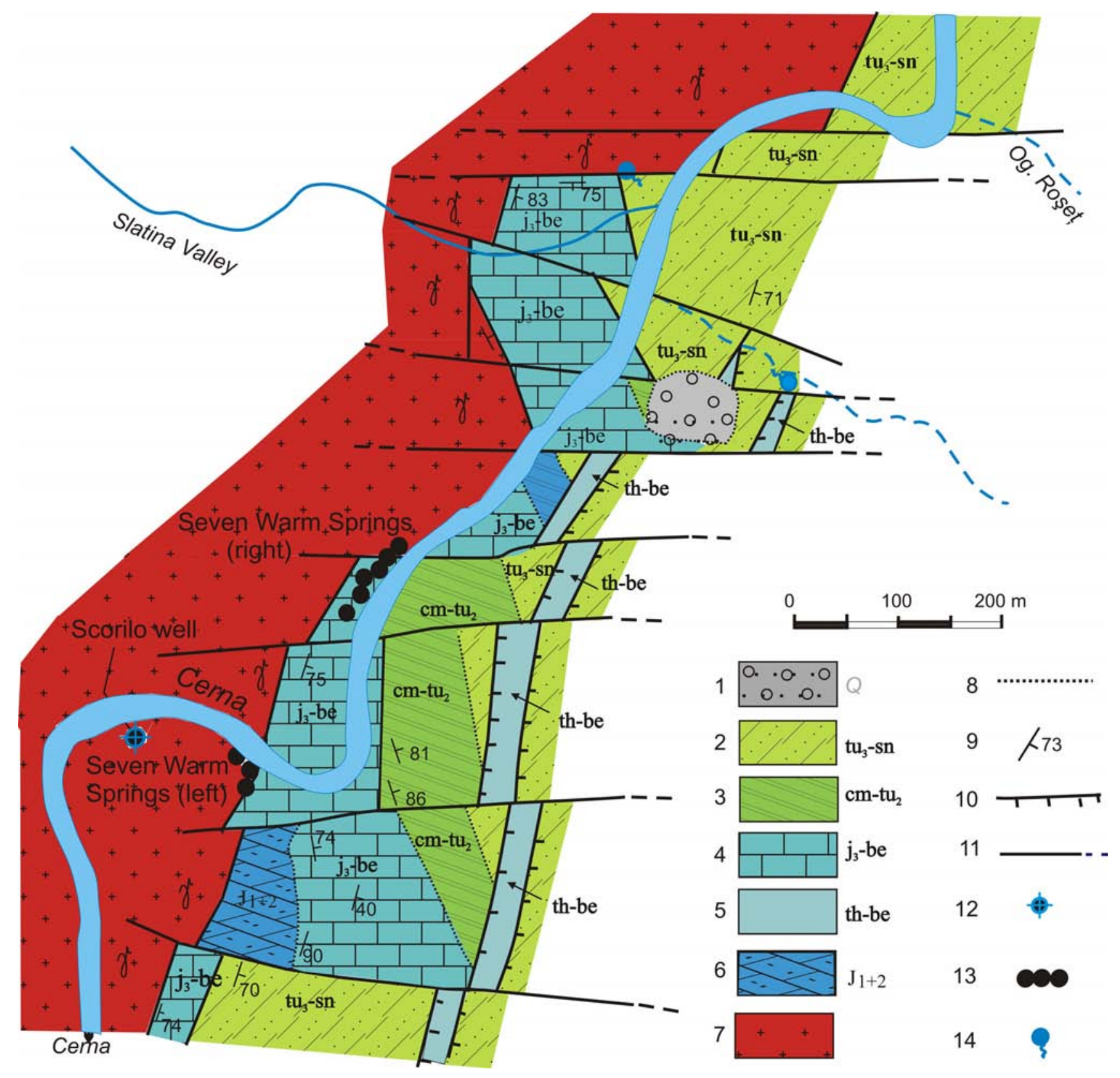

Fig. 6. Geological map between Ogaşul lui Roşeț and Şapte Izvoare Calde: 1 -Quaternary deposits; 2 - sandstones, siltstones, argillites (Wildflysch Formation); 3 -Nadanova Layers; 4 -marly limestones, calcirudites; 5 - Tithonic-Berriasian limestones; 6 - conglomerates, sandstones 7 - Cerna Granite; 8 -unconformity limit; 9 - dip and strike of the rock layers; 10 - local thrust; 11 -fault; 12 - well; 13 - thermo-mineral spring; 14 - cold spring (Terteleac et al., 1989, modified).

The Hygeea Spring is located on the tectonic contact between the Upper Jurassic limestones and the Iuta Layers, at $40 \mathrm{~m}$ downstream from the Hercules Spring, on the same slope, at only $0.8 \mathrm{~m}$ relative altitude. The flow rate and the temperature vary similarly with the rates of the Hercules Spring. Water temperature varied between $35^{\circ} \mathrm{C}$ and $46^{\circ} \mathrm{C}$, while the flow rates varied between $0.2 \mathrm{l} / \mathrm{s}$ and $0.03 \mathrm{l} / \mathrm{s}$, for a total mineralization of 1.12-3.5 g/l. The water of the spring is composed of $\mathrm{Na}-\mathrm{Ca}-\mathrm{Cl}$, along with low concentrations of bromide, iodide, low-sulfide type.

The Despicătură Spring is situated $8 \mathrm{~m}$ downstream from the Despicătură Cave, at the level of the Cerna riverbed. As long as the entrance of the Hercules Cave was barred by a 4 $\mathrm{m}$ high, concrete dam, the Despicătură Cave was functioning as an overfill drainage for the aquifer. The thermal stream from the cave dried out after the dam dismantling. The hydrodynamic link between the Hercules, Hygeea, Despicătură, and Apollo II springs has been highlighted by taking advantage of the experimental draining of the water accumulated behind the Hercules Dam (Povară, 1973).

Apollo I Spring. The source is located within the Apollo Pavilion. The water emerges on the tectonic contact between the Upper Jurassic limestones and the Iuta Layers. Before 1982, the last year when systematic measurements were made, water had an artesian character $(+6 \mathrm{~m})$. The water is of $\mathrm{Na}-\mathrm{Ca}-\mathrm{Cl}$ composition type, along bromide, iodide, sulfide type. The interception of the natural supply route of the spring, on the occasion of digging for a foundation, some $65 \mathrm{~m}$ upstream of Apollo I, created a new groundwater emergence, which became the dominant flow rate. 
NV

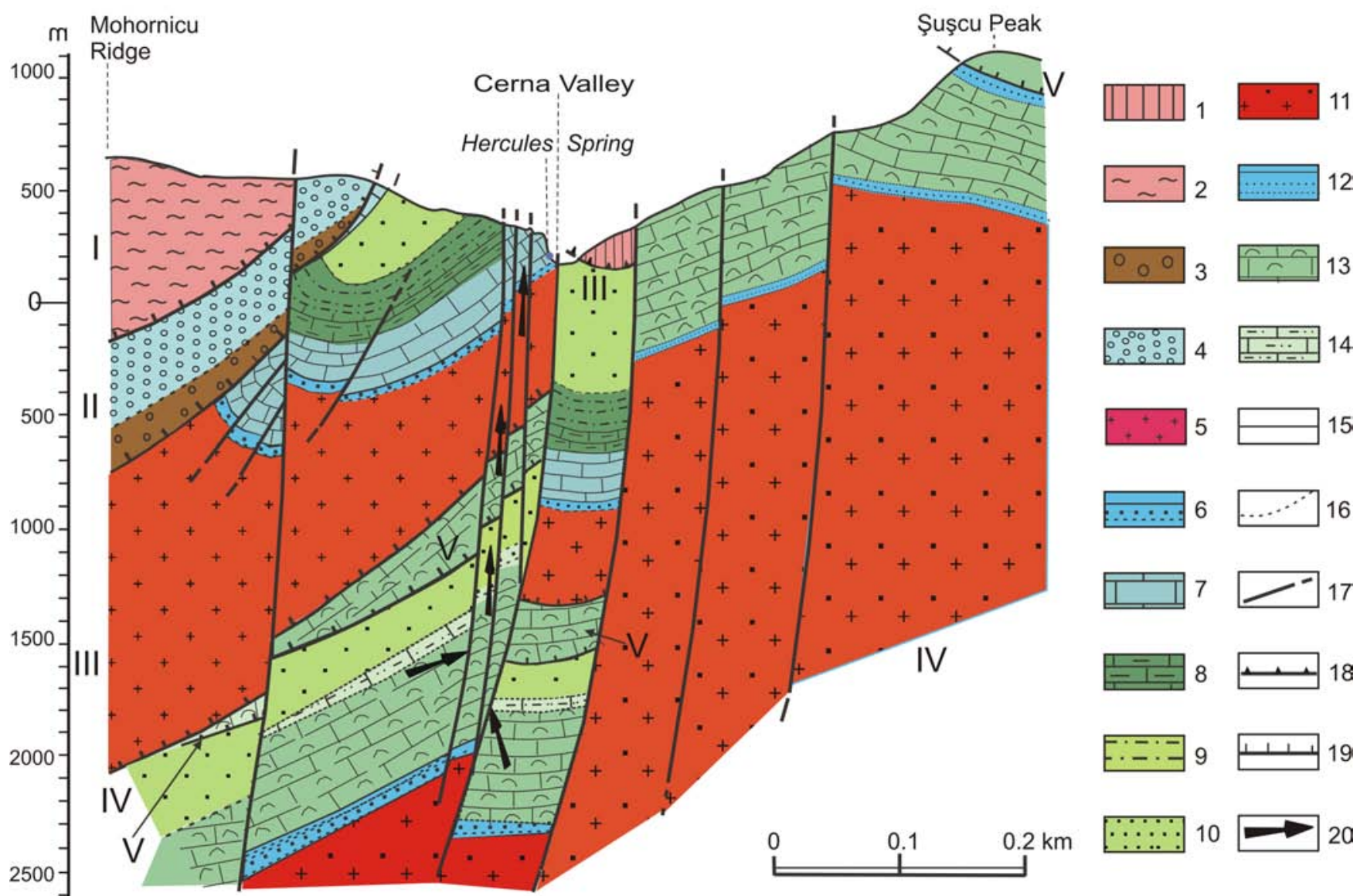

Fig. 7. Geological structure in the Hercules Spring area. The Getic Nappe: units of the internal Danubian Autochthonous:

I - upper unit: 1 - gneisses, micaschists, quartzites; 2 - Permian retrometamorphic rocks; II - median unit: 3 - Permian conglomerates and sandstones, 4 - Liassic sandstones and conglomerates; III - lower unit: 5 - Cerna Granite; 6 - sandstones, limestones and sandstone-like limestone's $\left(J_{1}-J_{2}\right) ; 7$ - massive limestones ( $J_{3}$ - Berriasian); 8 - limestones and marly limestones (Berriasian-Hauterivian); 9 - marly limestones, siltstones (Barremian-Aptian - Iuta Layers); 10 - sandstones, siltstones, clays (Turonian-Senonian); units of the external Danubian Autochthonous: IV - Mehedinţi Unit: 11 - Permian metamorphic and granitoid rocks; 12 - sandstones and sandstone-like limestones $\left(J_{1}-J_{2}\right) ; 13$ - laminated and massive limestones $\left(J_{3}+\right.$ Barremian-Aptian); 14 - marly limestones and marly siltstones (Cenomanian-Turonian - Nadanova Layers, idem 10); V - Cerna Unit (idem 13): 15 - conformity limit; 16- unconformity limit; 17 - fault; 18-regional thrust; 19- local thrust; 20 - flow paths of the heated fluids (Pop, din Terteleac et al., 1989, modified).

Apollo II Spring is caught in a ca. $4 \mathrm{~m}$ high, concrete basin, from which it is exploited by pumping. The water temperature, measured during the first days after the opening of the source, was $59.8^{\circ} \mathrm{C}$, while the flow reached $8.51 / \mathrm{s}$. For the years 1989, 1990, and 1994, the flow rates varied between $1.5 \mathrm{l} / \mathrm{s}$ and $3.57 \mathrm{l} / \mathrm{s}$, temperatures between $44.8^{\circ} \mathrm{C}$ and $50.2^{\circ} \mathrm{C}$, the total mineralization diminished to 2.7-2.8 $\mathrm{g} / 1$, while the average concentration of the dissolved $\mathrm{H}_{2} \mathrm{~S}$ was $23.4 \mathrm{mg} / \mathrm{l}$; the water characteristics remained unchanged.

The flow rates in this group of springs are high, when compared to those of the other thermo-mineral sources, due to the descending supply of the cold water. The variations of flow rate, temperature and mineralization are maximal at the Hercules Spring and are attenuated towards the south, i.e. towards the junction area of syncline to graben. This is the group of springs where the hydrodynamic interference between the water of the structures (syncline and graben) and between the two types of mixing water (descending - cold - nonmineralized and ascending - thermal - mineralized) is maximal.

\section{Diana Group}

This group includes four springs (Diana I, Diana II, Diana IV, Hebe) and the Diana III Well, situated in the central area of the old spa.

Diana I and II Springs. The emergence points were situated in a small natural cavity, developed on the right bank of Cerna, at $11 \mathrm{~m}$ relative altitude, on the Diana Fault, which brings into contact the Iuta Layers and the Upper Jurassic limestones. Data concerning the physico-chemical parameters differ depending on the institution that obtained them, and on the time period. Before the year 1975, the flow rates varied between 1.1-2.5 $1 / \mathrm{s}$, while the temperatures oscillated between $49-51^{\circ} \mathrm{C}$. After this year, the flow rates varied between $0.26-0.6 \mathrm{l} / \mathrm{s}$, while the temperatures fluctuated between $47.5-51^{\circ} \mathrm{C}$. The mineralization variations fell into the 4.39-6.27 g/l interval, the waters were unchanged their $\mathrm{Na}-\mathrm{Ca}-\mathrm{Cl}$, bromide, iodide sulfide character. In the spring waters, eruptions of free gases with pulsating character could be noticed. 
Diana IV Spring (Izvorul de Picioare). It emerges from the marly limestones in the left bank of Cerna, in the flooding area. No systematic flow measurements have been undertaken on this spring. Simion (1987) cited temperatures of $34-46^{\circ} \mathrm{C}$ and a mineralization of water which varies between 5.02-5.35 g/l. The water is of $\mathrm{Na}-\mathrm{Ca}-\mathrm{Cl}$ composition type, along with bromide, iodide, sulfide type.

The Diana (Diana III) Well. This Well is located on the Diana Fault, on the right bank of Cerna and has been drilled down to a depth of $260 \mathrm{~m}$, where the granite basement has been intercepted. It crossed Quaternary formations and marly limestones (0-100 m), and then the Malm-Neocomian limestones $(100-240 \mathrm{~m})$ and the Dogger spathic limestones (240-259 m). The initially obtained flow rate was $0.15 \mathrm{l} / \mathrm{s}$, with the temperature of $70^{\circ} \mathrm{C}$. During 1989-1990 and 1994 time periods, flow rates varied between $0.033-0.053 \mathrm{l} / \mathrm{s}$, with temperatures of $51.8-54.4^{\circ} \mathrm{C}$, mineralization from 2.58 to $5.82 \mathrm{~g} / \mathrm{l}$ and an average value of the $\mathrm{H}_{2} \mathrm{~S}$ concentration of 51 $\mathrm{mg} / \mathrm{l}$. The water is of $\mathrm{Na}-\mathrm{Ca}-\mathrm{Cl}$ composition type, along with bromide, iodide, high-sulfide type.

Hebe Spring. This spring is caught in the basement of the Hebe Spa, on the limestone-marly limestone contact. The physical-chemical parameters have not been monitored during the last 20 years. Simion (1987) mentioned flow rates of $0.8 \mathrm{l} / \mathrm{s}$, temperatures of $22-30^{\circ} \mathrm{C}$ and a mineralization of 1.1-1.6 $\mathrm{g} / \mathrm{l}$, values much lower than those of the other sources in the group.

\section{Neptun Group}

It includes the Venera I, Venera II, Neptun III springs and the Neptun I+IV and Neptun II wells, all situated along the Neptun Fault.

Neptun $I+I V$ source consists in the wells Neptun I, dug in 1894 down to a depth of $276 \mathrm{~m}$, and Neptun IV, drilled in 1968, at a depth of $350 \mathrm{~m}$ depth. The two wells are hydrodynamically linked. The aquifer horizon encompasses the Upper Jurassic limestones, a fact which also explains the level of the flow rates. Experimental pumping tests, carried out in the Neptun IV Well, have caused diminishing to the disappearance of the Diana Group sources flow rates, showing the hydrodynamic link between them.

The water is of $\mathrm{Na}-\mathrm{Ca}-\mathrm{Cl}$ composition type, along with bromide, iodide, and high-hydrogen sulfide type, with total mineralization varying from $5.38 \mathrm{~g} / 1$ to $6.28 \mathrm{~g} / 1$ and an average concentration value of $26.6 \mathrm{mg} \mathrm{H}_{2} \mathrm{~S} / \mathrm{l}$, as effect of the dilution with karst waters. This is the source with the southernmost position, in which tracers injected in the sinkholes from the Cerna Syncline and the Cerna Graben have been identified.

Neptun II (Anteu) Well. It is located in the right bank of Cerna, on the Neptun Fault. Down to the final depth of 316 $\mathrm{m}$, the Well crossed marly limestones $(0-70 \mathrm{~m})$, then greyblackish or black, sometimes breccious limestones. The spring water belongs to the $\mathrm{Na}-\mathrm{Ca}-\mathrm{Cl}$, bromide, iodide, high-sulfide type, with mineralization between 6.16-6.86 g/l and an average concentration of $62.2 \mathrm{mg} \mathrm{H}_{2} \mathrm{~S} / \mathrm{l}$. The flow rates are characterized as pulsating, due to a biphasic flow (water-gas).
Neptun III (Argus) Spring. The emergence is situated on the same fault, only $8 \mathrm{~m}$ away from the previous well, but at a higher level. The flow rates recorded in the years 1972-1974 oscillated between $0.05-0.18 \mathrm{l} / \mathrm{s}$, those registered during the period 1974-1986 fluctuated between 0.03-0.09 1/s, while the ones established during this study fall into the 0.016 $0.07 \mathrm{l} / \mathrm{s}$ interval. The temperature variations are more homogeneous, being included in a ca. $4^{\circ} \mathrm{C}$ interval (46.0$50.2^{\circ} \mathrm{C}$ ). The chemical characteristics of the water are identical to the ones of the other sources in the group; the total mineralization varies between $6.17 \mathrm{~g} / 1$ and $6.46 \mathrm{~g} / 1$, while the average concentration of $\mathrm{H}_{2} \mathrm{~S}$ is $53.6 \mathrm{mg} / \mathrm{l}$.

To these sources one may add two more springs, also located on the level of the Neptun Fault, but on the left slope of Cerna.

Venera I Spring is situated in the basement of a spa pavilion, inaccessible for systematic measurements. The flow rates varied between 0.1-0.5 $\mathrm{l} / \mathrm{s}$, the temperatures fluctuated between $36-41^{\circ} \mathrm{C}$, while the TDS oscillated between 6.92 $7.89 \mathrm{~g} / \mathrm{l}$ (data from the IBTH archive).

Venera II Spring emerges at the level of the easily flooded riverbed, with an approximate flow rate of $0.05 \mathrm{l} / \mathrm{s}$, temperatures of $35-40^{\circ} \mathrm{C}$ and TDS of $6.36-6.92 \mathrm{~g} / \mathrm{l}$ (data from the IBTH archive).

\section{Southern Sping Group}

Traian Well was drilled in 1969, in the left bank of Cerna, down to a depth of $577.5 \mathrm{~m}$. It successively crossed Quaternary alluvia $(2 \mathrm{~m})$, the calcareous sandstones and the marly limestones pertaining to the Nadanova Layers (2-153 $\mathrm{m})$, Jurassic-Cretaceous limestones (153-400 m), Liassic sandstones $(400-420 \mathrm{~m})$ and the granite basement (420$577.5 \mathrm{~m}$ ). The last type of rock, intensely fissured, shows submillimeter voids, resulted from the process of the weathering and leaching of feldspars. Experimental data obtained after the Well has been performed, have shown two intervals with different aquifer properties (Vasilescu and Liteanu, 1973):

- for the 295.6-453 m interval, an artesian flow rate $(+52$ $\mathrm{m} ; 2.0 \mathrm{l} / \mathrm{s}$ ), with the temperature of $47^{\circ} \mathrm{C}$, has been obtained;

- for the 461-577.5 m interval, entirely located in granite, an artesian flow rate $(+50 \mathrm{~m} ; 5.6 \mathrm{l} / \mathrm{s})$, with an initial temperature of $62^{\circ} \mathrm{C}$, has been obtained.

In the years 1989-1990 and 1994, the flow rates varied between 5.2 and $7 \mathrm{l} / \mathrm{s}$, while the temperatures fluctuated between 56.7 and $59.5^{\circ} \mathrm{C}$. The source water is composed of $\mathrm{Na}-\mathrm{Ca}-\mathrm{Cl}$, bromide, iodide, high-sulfide type, with total mineralization varying depending on the flow rate, between $7.56 \mathrm{~g} / 1$ and $8.43 \mathrm{~g} / \mathrm{l}$, the highest concentrations of the dissolved $\mathrm{H}_{2} \mathrm{~S}$ being recorded here (the maximal reached value being $116 \mathrm{mg} / \mathrm{l}$, while the average value is $73.6 \mathrm{mg} / \mathrm{l}$ ).

Decebal Well was drilled to the final depth of $597.7 \mathrm{~m}$. It crossed carbonate sandstones $(0-50 \mathrm{~m})$, sandstone-like limestones (50-192.5 m), compact limestones with dissolution voids (192.5-410 m), brownish compact limestones and whitish limestones $(410-461 \mathrm{~m})$, then the Cerna Granite. Hydrogeological tests have shown that the karstified fissures network of the Mesozoic limestones (especially their bottom part) holds a potential artesian flow rate $(+45 \mathrm{~m})$ of $2.89 \mathrm{l} / \mathrm{s}$, 
at $39.5^{\circ} \mathrm{C}$, whereas the granites have also an artesian aquifer potential of only $0.1 \mathrm{1} / \mathrm{s}$, at $38.5^{\circ} \mathrm{C}$. After the commissioning in 1969, the flow rates went constantly down, until 1982, since then, they have maintained a rate around the value of $1.3 \mathrm{l} / \mathrm{s}$.

The water of the source is of $\mathrm{Na}-\mathrm{Ca}-\mathrm{Cl}$, bromide, iodide, sulfide type, with concentrations of mineral salts of 7.69$8.58 \mathrm{~g} / \mathrm{l}$ and an average concentration of $63.6 \mathrm{mg} \mathrm{H}_{2} \mathrm{~S} / 1$.

Stadion Well. It was drilled to the depth of $800 \mathrm{~m}$, successively crossing the Wildflysch Formation (0-125 m), the Jurassic-Cretaceous sandstones and limestones and the Cerna Granite. The flow rates initially recorded from the lower part of the limestones and from granites $(1.5 \mathrm{l} / \mathrm{s}$ at $35.5^{\circ} \mathrm{C}$ ) decreased to $0.5 \mathrm{l} / \mathrm{s}$ at $32-34^{\circ} \mathrm{C}$. The water is of Na$\mathrm{Ca}-\mathrm{Cl}$ composition, with mineral salts concentrations of 7.93-8.96 g/l and an average concentration of $47.8 \mathrm{mg} \mathrm{H}_{2} \mathrm{~S} / 1$.

Fabrica de Var Well was drilled to a depth of $921 \mathrm{~m}$ and crossed Quaternary alluvia (0-5 m), the Wildflysch Formation $(5-135 \mathrm{~m})$, calcareous sandstones $(135-235 \mathrm{~m})$, Jurassic-Cretaceous limestones (235-695 m) and granites (695-921 m).

The productive interval, located in the granite, provided an artesian flow of $4.5 \mathrm{1} / \mathrm{s}$, at $42.5^{\circ} \mathrm{C}$, the water having pronounced mineral salts content, varying between 7.85$8.34 \mathrm{~g} / \mathrm{l}$ and an average $\mathrm{H}_{2} \mathrm{~S}$ content of $30.4 \mathrm{mg} / \mathrm{l}$.

The water belongs to the $\mathrm{Na}-\mathrm{Ca}-\mathrm{Cl}$, bromide, iodide, sulfide composition type.

Some conclusions can be drawn from this presentation of the thermo-mineral sources:

- All natural springs are located on faults (or in their immediate vicinity), which bring into contact the limestones and the non-karst formations.

- The highest total flow rates have been recorded from the Jurassic-Cretaceous limestones and from the Cerna Granite, affected by a porosity of open fissures.

- Between the sources from the Hercules, Diana, and Neptun groups there are hydrodynamic interferences.

- The flow rates and the temperatures registered at wells diminished by $15-50 \%$, on intervals varying from a few months to a few years after the commissioning of the wells.

- The sources from the northern groups of the reservoir (Şapte Izvoare Calde and Hercules) show a low mineralization, but a clear $\mathrm{Na}-\mathrm{Cl}$ facies, as well as low, but persistent, concentrations of $\mathrm{H}_{2} \mathrm{~S}$. Sources from the central and southern groups (Diana, Neptun, Vicol) are stronger mineralized, the predominant anion being $\mathrm{Cl}^{-}$, whereas from the cations the predominant is $\mathrm{Na}^{+}$; the $\mathrm{Ca}^{2+}$ percentage is significant, when it is compared to that recorded at the northern sources, where the highest concentrations in $\mathrm{H}_{2} \mathrm{~S}$ have been measured.

\section{Hercules karst system}

Using the systemic analysis (Mangin, 1975) of the Hercules Spring flow rates and of the rainfall (1979-1983), the following results have been obtained:

- The classified flow rates show the activation of some overflow conduits towards the Despicătură Cave and the Apollo and Diana springs, at flow rates exceeding 68 1/s.

- The recession curves show that the flow rates are balanced around the value of $15 \mathrm{l} / \mathrm{s}$, and the draining coefficient $(\alpha)$ varies very little $(0.0037-0.0031)$. The parameters of a recession are rendered in Table 6.

- The value of the $k$ coefficient is characteristic for a binary karst, and the $\varepsilon$ parameter reaches high values, significant for the strong influence of the superficial component on the supply of the spring.

- The simple correlogram of the flow rates is characteristic for a karst system in the structure of which two subsystems (components) can be found, and the flow rates spectrum (Fig. 8a) confirms this conclusion by the presence of two distinct cutting frequencies $\left(\mathrm{f}_{\mathrm{c}}\right)$ :

- The first (0.096) corresponds to an interval of 11 days, and is due to the information contained by the lower part of the aquifer. Most of the thermal sources of the Neptun and Vicol groups are not influenced by the rainfall, so the value does not characterize the thermal component of the water mix, but a structure located between the drain and the profound zone.

- The second (0.184) corresponds to an interval of 5 days and characterizes the flow, which takes place at the level of the karst drain situated at the upper part of the submerged karst.

- The cross-correlogram (Fig. 8b) indicates a low karstification of the system.

- The regularization time of 41 days indicates an inertial system which cannot be explained but by the stability of the flow parameters at the level of the warm and mineralized ascending supply.

Table 6. Parameters of the recession from the 24/06/1979 $(Q=82.2 \mathrm{l} / \mathrm{s})-9 / 08 / 1979(Q=16.3 \mathrm{l} / \mathrm{s})$.

\begin{tabular}{|c|c|c|c|c|c|c|c|c|c|c|c|c|}
\hline$\alpha$ & $\eta$ & $\mathrm{E}$ & $Q_{R O}(l / s)$ & $\begin{array}{c}Q^{\prime} o \\
(l / s)\end{array}$ & $\begin{array}{c}q 0 \\
(l / s)\end{array}$ & $\begin{array}{c}t_{i} \\
(\text { days })\end{array}$ & $\begin{array}{c}\mathrm{V}_{\operatorname{din}} \times 10^{6} \\
\mathrm{~m}^{3}\end{array}$ & $\begin{array}{c}\mathrm{V}_{\operatorname{din}}^{\prime} \times \\
10^{6} \mathrm{~m}^{3}\end{array}$ & $\begin{array}{c}\mathrm{V}_{\text {inf }} \times 10^{6} \\
\mathrm{~m}^{3}\end{array}$ & $i$ & $k$ & $\begin{array}{c}\mathrm{V}_{\text {anual }} \times \\
10^{6} \mathrm{~m}^{3}\end{array}$ \\
\hline 0.0031 & 0.0323 & 0.233 & 16.60 & 15.10 & 26.79 & 31 & 0.469 & 0.426 & 0.014 & 0.638 & 0.454 & 0.939 \\
\hline
\end{tabular}

\section{POSSIBLE MODEL FOR THE FUNCTIONING OF THE THERMO-MINERAL AQUIFER}

A functional model of this complex aquifer structure has been presented by Simion (1982), who stated that "the thermo-mineral reservoir from Băile Herculane represents the result of the mixing of three hydrogeological components: (1) a cold component (in the highest percentage), (2) a heating component - hot vapors coming from the depth, which heat up cold waters and (3) a mineralizing component, originated from outside the Cerna Graben, which mineralizes already heated waters".
The cold component, provided by a karst flow and the geothermal anomaly (caused by an input of hot fluids) have been proven, even though there are some contradictory data. However, there is not sufficient information which may explain the mineralization origin. The mineralizing component might come from outside the graben, but this has to be demonstrated. The highest values of the total mineralization (?) and of the water temperature have been recorded at the southern groups, and the lowest level of chemical rebalancing registered by the $\mathrm{Na}-\mathrm{K}-\mathrm{Mg}$ geothermometer has been measured at the Neptun sources. 

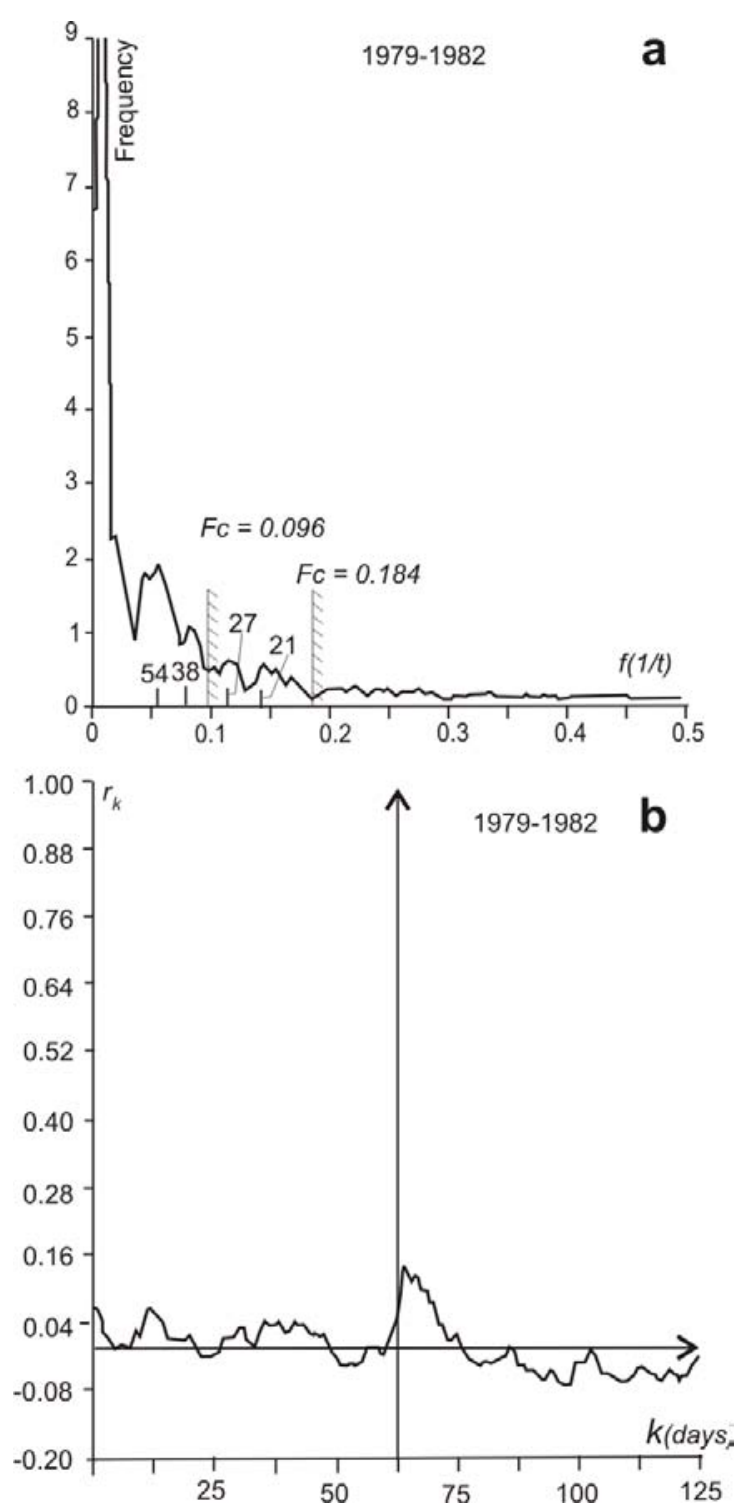

Fig. 8. (a) Flow rates spectrum and (b) cross-correlogram at Hercules Spring $\left(r_{k}=\right.$ correlation coefficient).

Starting from these facts, Mitrofan and Povară (2000) promoted the idea that in this area, on the Neptun and Vicol faults, the main input of deeply originating, hot fluids, takes place. Northward and, respectively, southward with reference to Neptun, two convective cells are developed (with counter-clockwise and, respectively, clockwise circulation), by which a fraction of the deeply originating, hot fluids, is sent to the other sources.

In the flow process, the mixing with karst water takes place, a fact which causes the modification of the chemical facies and of the temperatures.

In the sketch displayed in Fig. 9, we present a functioning model of the thermo-mineral reservoir from Băile Herculane, which highlights the role played by the karst formations and processes in supplying the deposit.

\section{CONCLUSIONS}

The limestones of the Cerna Syncline form an aquifer structure, parallel to the graben, with marked southward inclination, open to the groundwater flow only in that direction. The southern portion of the structure is in contact with the limestones from the graben, with which a water exchange takes place;
The supply of the aquifer is from the north, through the diffuse infiltrations in the thalweg of the valleys crossing the limestones, and by direct infiltrations from rainfall. Hercules Cave represents the main discharge path for the aquifer structures of the Cerna Syncline;

The flow paths of the cold water, from the north of the aquifer towards Hercules, intercept an area with thermal and mineralized water; their flow rate, temperature and chemical composition may be considered as constant. The thermal water penetration area is localized towards the western flank of the syncline; the cold flow, directly depending on the rainfall volume, is very fluctuant and causes different dilutions of the thermal and mineralized flows;

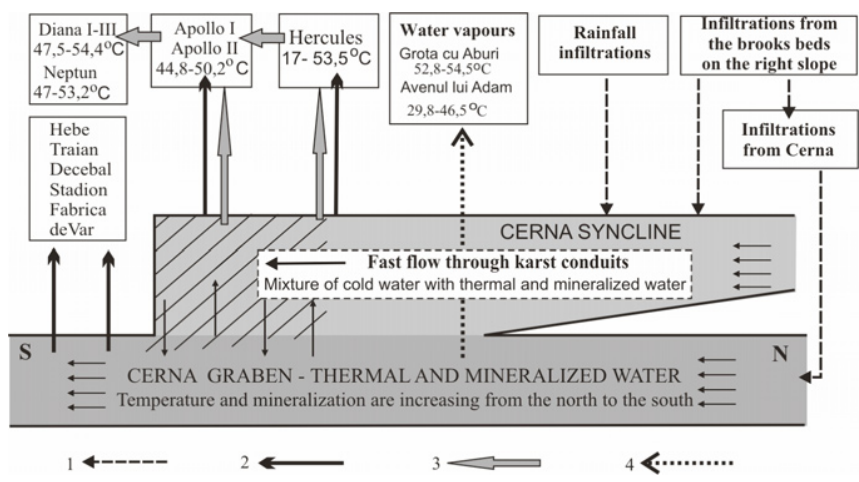

Fig. 9. Organization and functioning of the thermo-mineral aquifer complex from Băile Herculane: 1 - descending cold waters, originating from rainfall, infiltrated on the surface of the limestones, and infiltrations from the brooks beds; 2 - ascending thermal and mineralized waters from the Cerna Graben; 3 - mixing waters; 4 -water vapors.

Cold karst waters are influencing the character of physical-chemical instability of the Hercules Spring. The increases in flow rate area inversely proportional to decreases of the temperature and changes of the chemical composition. The mixing area of the two types of water is located to the south of Valea Seacă;

At the karst drain level, there are several known water outputs, towards the Despicătura, Apollo I and Apollo II springs; their flow rates are maximal at values higher than 70 1/s for the Hercules Spring;

The karst flow, through the channel network, generates an "export" of thermal energy towards the adjacent areas; The Hercules System is weakly karstified; it has an average inertia, with high memory effect, due to an allogenic input and to a modest submerged karst.

Acknowledgements. We thank two anonymous reviewers for their suggestions and improving the English of the paper.

\section{R E F E R E N C E S}

Codarcea, A. 1940, Vues nouvelles sur la tectonique du Banat mèridional et du Plateau de Mehedinti. Anuarul Institutului Geologic al României, XX, 74 p.

Bercia, I. 1975, Metamorfitele din partea centrală şi de sud a masivului Godeanu. Studii Tehnice şi Economice Institutul de Geologie şi Geofizică, Seria I (12), 159 p.

Codarcea, A., Bercia, I., Boldur, C., Constantinof, D., Maier, O., Marinescu, F., Mercus, D. \& Năstăseanu, S. 1967, Geological structure of the southwestern Carpathians. $13^{\text {th }}$ International Geological Congress, Guide to excursion 49 AC, Romania, $50 \mathrm{p}$. 
Codarcea, A., Năstăseanu, S. 1964, Contribuții la cunoaşterea stratigrafiei depozitelor calcaroase din bazinul Văii Cerna şi de la Cazane (Dunare). Studii şi Cercetări de Geologie, 9 (2): 241-250.

Cosma, C., Mastan, I., Znamirovschi, V. \& Golopența, N. 1981, Cercetări asupra radioactivității gazelor naturale din Valea Cernei (III). Studii şi Cercetări de Fizică, 33 (7): 635-638.

Gaşpar, E. 1994, Trasori în sisteme acvifere. Ed. Academiei Române, Bucureşti, 234 p.

Gaşpar, E., Simion, G. 1985, Tracer research on the dynamics of underground waters in the Cerna Valley (Southern Carpathians, Romania). Theoretical and Applied Karstology, 2: 183-197.

Giggenbach, W.F. 1986, Graphical techniques for the evaluation of water/rock equilibration conditions by use of $\mathrm{Na}, \mathrm{K}, \mathrm{Mg}$ and Ca-contents of discharge waters. Proceedings of the $8^{\text {th }}$ New Zeeland Geothermal Workshop, University of Auckland, Auckland, 246: 37-44.

Mangin, A. 1975, Contribution a l'étude hydrodynamique des aquiferès karstiques. Annales de Spéléologie, 29 (3): 283-332; 29 (4): 495-601; 30 (1): 21-124.

Marin, C. 1984, Hydrochemical considerations in the lower Cerna river basin. Theoretical and Applied Karstology, 1: 173-183.

Mastan, I., Cosma, C. \& Znamirovschi, V. 1982, Date noi asupra compoziției şi originii gazelor naturale emanate din sursele geotermale de pe Valea Cernei şi Valea Mehadica. Studii şi Cercetări de Fizică, 34 (6): 579-585.

Mitrofan, H., Povară, I. 1992, Delineation of a thermal water carrying karstic conduit by means of thermometric measurements in the Băile Herculane area (Romania). Theoretical and Applied Karstology, 5: 139-144.

Mitrofan, H., Povară, I. 2000, Methods for assessing the hydrogeological disarray associated to a reservoir dam built in a geologically complicated area. In Fragile territory-Research and Application on Hydrogeological Disarray in the World, $10^{\text {th }}$ International Congress of Geology, Italy, 33-38.

Mitrofan, H., Mafteiu, M., Povară, I. \& Mitruțiu, M. 1995, Electrometric investigations on the supply channels of Hercules Spring (Romania). Theoretical and Applied Karstology, 8 :126-136.

Murgoci, M.G. 1905, Sur l'existence d'une grande nappe de recouvrement dans les Carpates Méridionales. Buletinul Societătii de Stiințe (1907), XVI: 50-52.

Murgoci, M.G. 1910, The geological synthesis of the South Carpathians. Compte Rendu Congrés Géologique International, XI (Stockholm, 1910), p. 871-880.

Năstăseanu, S. 1967, Cretacicul superior din Valea Cernei şi date noi privind tectonica Munților Cernei (Banat). Dări de Seamă ale Comitetului Geologic, LIII (1): 401-411.

Năstăseanu, S. 1980, Géologie des Monts Cerna. Anuarul Institutului de Geologie şi Geofizică, LIV, 137 p.

Oncescu, N. 1953, Apele curative (minerale şi balneare) din RPR. Natura, 1: 15-27.

Papiu, C.V. 1960, Asupra originii mineralizatiei apelor termale de la Băile Herculane. Studii şi Cercetări de Geologie, 5: 41-57.

Pascu, M. 1968, Combaterea infiltrațiilor de ape reci la izvorul termal Hercules I. Hidrotehnica, Gospodărirea Apelor, Meteorologia, 14: 33-37.

Popescu Voitești, I. 1921, Étude géologique sur les sources minerales des Bains D'Hercule. Annales des Mines de Roumanie, 4 (3-4): 3-23.
Povară, I. 1973, Contributions à la connaissance des sources thermo-minérales de Băile Herculane. Travaux de l'Institute de Spéologie "Emile Racovitza", XII: 337-348.

Povară, I. 1980, Note sur la circulation souterraine des eaux dans les calcaires du bassin de Cerna. Travaux de l'Institute de Spéologie "Emile Racovitza", XIX: 237-241.

Povară, I. 1992, New data on the Hercules thermal aquifer, obtained by temperature measurements (Băile Herculane, Romania). Theoretical and Applied Karstology, 5: 127-138.

Povară, I., Lascu, C. 1978, Note sur la circulation souterraine de l'eau par le graben de Cerna. Travaux de l'Institute de Spéologie "Emile Racovitza", XVII: 193-197.

Povară, I., Marin, C. 1984, Hercules thermomineral spring. Hydrogeological and hydrochemical considerations. Theoretical and Applied Karstology, 1: 183-195.

Povară, I., Diaconu, G. \& Goran, C. 1972, Observations préliminaires sur les grottes influencées par les eaux thermo-minérales de la zone Băile Herculane. Travaux de l'Institute de Spéologie "Emile Racovitza", XI: 355-365.

Pricăjan, A. 1972, Apele minerale şi termale din România. Ed. Tehnică, Bucureşti, 296 p.

Simion, G. 1982, Hydrogeological studies on Cerna Valley basin, in order to establish a new hydrogeological protection perimeter for the Băile Herculane hydrothermal water. IPGG Archive, Bucharest.

Simion, G. 1986, Hydrogeological study and resource assessment of the Băile Herculane thermomineral water. IPGG Archive, Bucharest.

Simion, G. 1987, Geological project concerning the redevelopment of the thermomineral water sources from Băile Herculane, Caraş-Severin County. IPGG Archive, Bucharest.

Simion G, Popescu C. 1988, Sinteza datelor obținute din cercetările efectuate pentru apele termominerale de la Băile Herculane (Raport, nepublicat).

Simion, G., Ponta, Gh. \& Gaşpar, E. 1984, The dynamics of underground waters from Băile Herculane, Cerna Valley, Romania. Annales de la Société Géologiques de Belgie, 108: 245-249.

Slăvoacă, D., Feru, M., Geamanu, V., Simion, G., Golita, N. \& Lungu, P. 1978, Considerații hidrogeologice asupra ivirilor naturale de ape termale din România. Studii Tehnice şi Economice (Institutul de Geologie şi Geofizică, Seria E (13): 5-15.

Terteleac, N., Veliciu, S. \& Pop, Gr. 1989, Complex geological and geophysical research concerning the hydrostructure of the Hercules Spring, Băile Herculane. IPGG Archive, Bucharest.

Vasilescu, Gh., Liteanu, E. 1973, Noi surse de ape termominerale din zona stațiunii Băile Herculane. Hidrologia, E (11): 25-43.

Veliciu S., Năstăseanu S. \& Zamfir, A. 1983, Geothermal researches in the Cerna graben (Northern Segment), Geological Report, I.G.G. Archive, Bucharest.

Veliciu, S., Terteleac, N. \& Conovici, M. 1987, Information on Geological and Geophysical Works Performed in the Area of the Cerna Valley for Geothermal Waters. Geological Report, I.G.G. Archive, Bucharest.

Visarion, M., Apostol, A. \& Ştefănescu, R. 1974, Contribuții geofizice la precizarea zonelor de ridicare spre suprafață a apelor termominerale de la Băile Herculane. Studii şi Cercetări Geologice, Geofizice, Geografice, Seria Geofizică, 12 (1): 135-144. 